\title{
Seasonal change in the foraging ecology of emperor penguins on the Mawson Coast, Antarctica
}

\author{
Roger Kirkwood ", Graham Robertson \\ Australian Antarctic Division, Channel Highway, Kingston 7050, Tasmania, Australia
}

\begin{abstract}
We investigated the foraging location, diving behaviour, detary composition, feeding rates and foraging trip durations of emperor penguins Aptenodytes forsteri raising chicks at the Auster and Taylor Glacier colonies on the Mawson Coast of Antarctica in the winter, spring and early summer of 1993, to examine seasonal changes in the penguins' foraging ecology. As day-length increased after winter, the penguins' daily swimming time increased from $7.83 \pm 1.50 \mathrm{~h}$ in August to $12.23 \pm 1.25 \mathrm{~h}$ in September and $12.95 \pm 1.24 \mathrm{~h}$ in October. Accordingly, the penguins' dive rate increased from $92.7 \pm$ 28.5 to $149.4 \pm 23.4$ and $161.6 \pm 19.3$ dives $\mathrm{d}^{-1}$ in the respective months. The birds targeted prey in the vicinity of the continental slope mainly at depths $<100 \mathrm{~m}$, although some individuals frequently hunted at depths $>200 \mathrm{~m}$, and the maximum depth achieved was $438 \mathrm{~m}$. Antarctic krill Euphausia superba were the most common prey taken overall, $41 \%$ of the diet by mass, and dominated the diets between August and October. The contribution of Antarctic krill to the diet reduced over time from $68 \%$ in August to $1 \%$ in early December. In November, the glacier squid Psychroteuthis glacialis dominated the diet ( 47 to $63 \%$ ), and in early December the diet comprised various species of fish, Trematomus species $(27 \%)$, Pagothenia borchgrevinki $(24 \%)$, and Pleuragramma antarcticum $(8 \%)$, and squid, $P$. glacialis $(13 \%)$ and Alluroteuthis antarcticus $(9 \%)$. The birds' prey consumption rates more than doubled between late winter and early summer, from $4.0 \pm 1.0$ to $8.7 \pm 1.7 \mathrm{~kg} \mathrm{~d}^{-1}$ spent foraging; these values are equivalent to metabolisable energy intakes of $628 \pm 134$ and $1422 \pm 308 \mathrm{~kJ} \mathrm{~kg}^{-1} \mathrm{~d}^{-1}$, respectively. During brooding (late winter to early spring), females spent less time at sea than males $(8.7 \pm 2.7$ vs $17.7 \pm 3.8 \mathrm{~d}$ ); thereafter trip durations of both sexes were similar and declined from $15-19 \mathrm{~d}$ in spring to $<10 \mathrm{~d}$ in early summer. Between hatching and about $1 \mathrm{wk}$ prior to fledging each parent fed its chick 7 or 8 times. To raise a chick, females and males consumed approximately 410 and $470 \mathrm{~kg}$ of prey respectively, or $880 \mathrm{~kg}$ for each breeding pair. Seasonal variations in the penguins' foraging were probably influenced by fluctuating sea-ice conditions, differences in the prey types available, changes in day-length toward summer, and increasing demands of the growing chicks.
\end{abstract}

KEY WORDS: Emperor penguin Antarctica S Seasonal change Sea-ice Foraging ecology Diving behaviour - Diet - Prey consumption

\section{INTRODUCTION}

Fisheries in Antarctic waters compete with higher predators for the same prey (Croxall et al. 1984, Ichii et al. 1996), and there is the potential in future for fisheries pressure to increase (Nicol \& de la Mare 1993). To minimise the impact of the fisheries on the predator populations requires both a diligent management

•E-mail: roger_kir@antdiv.gov.au regime and an understanding of the trophic relationships between Antarctic species, which may be highly variable. A major source of variability in trophic relationships in Antarctic waters is the extreme contrast in conditions between summer and winter. During summer the sun remains up for several weeks and the seaice around coastal areas reaches its minimum extent, whereas during winter the sun lies below the horizon for several weeks and a $1 \mathrm{~m}$ thick cover of fast-ice covers the sea surface for up to $100 \mathrm{~km}$ from the coast (Zwally et al. 1983). The foraging strategies of Antarc- 
tic marine species are intrinsically linked to this seasonality in solar influence and sea-ice cover. It is important to assess seasonal variations in the trophic relationships of Antarctic species to develop management strategies designed to ensure the conservation of the Antarctic ecosystem.

Antarctic seabirds are abundant predators in Antarctic waters (Croxall 1984). Generally, the seabirds are stimulated by the seasonality in the Antarctic environment to raise their young through spring and fledge them in summer when the foraging conditions for the fledglings are presumably most amenable. Conforming with this pattern is the largest seabird, the emperor penguin Aptenodytes forsteri. These penguins have the longest chick raising period of any Antarctic seabird $(5 \mathrm{mo}$ ) and must hatch their chicks in July in order to fledge them in early December (Prévost 1954). This lengthy chick rearing period, which follows on from a 4 mo courtship and incubation period, binds adult emperor penguins to the vicinity of the colonies for much of the year, and requires them to catch sufficient prey for themselves and their chicks between mid-winter and early summer.

Our knowledge of emperor penguin foraging ecology comes principally from single season studies that have concentrated on few aspects of the penguins' foraging ecology. Studies have assessed the birds' diving behaviour (Kooyman et al. 1971, Kooyman \& Kooyman 1995), diet (Gales et al. 1990, Robertson et al. 1994,
Pütz 1995 and references therein), feeding rates (Robertson \& Newgrain 1996), and foraging locations (Ancel et al. 1992). Despite this body of work, no studies have examined a range of aspects of the birds' foraging ecology in the context of the seasonally fluctuating environment in which the emperor penguins must forage. In an earlier study we assessed the foraging ecology of female emperors in winter, which precedes the period of chick rearing (Kirkwood \& Robertson 1997 a). In this study, we report on seasonal changes in the penguins' foraging ecology during the 5 mo period of chick care

\section{MATERIALS AND METHODS}

General. Our study was undertaken at Auster colony $\left(67^{\circ} 23^{\prime} \mathrm{S}, 64^{\circ} 04^{\prime} \mathrm{E}\right)$ and Taylor Glacier colony (67. $28^{\prime}$ $\left.\mathrm{S}, 60^{\circ} 54^{\prime} \mathrm{E}\right)$ which lie $150 \mathrm{~km}$ apart on the Mawson Coast of Antarctica (Fig. 1). In 1993 Auster colony contained 13300 breeding pairs of emperor penguins and at Taylor Glacier there were 2460 breeding pairs (Kirkwood unpubl. data).

Field work was conducted from the time of chick hatching until about $1 \mathrm{wk}$ before fledging (i.e. July to December), our stay being curtailed by deteriorating sea-ice. For most experiments, we selected penguins randomly from the stream of individuals either departing from or returning to the colony. The exception was in July and August when birds departing the colonies were males that were in a weakened condition after their extended winter fast and we selected robust-looking individuals to carry instruments, rather than selecting individuals at random, to improve our chances of recovering the devices. Specific techniques employed in the study are described in Kirkwood \& Robertson (1997a) and briefly outlined in the following sections. All birds were weighed to $\pm 0.1 \mathrm{~kg}$ and individually marked on the chest with 'Nyanzol' dye

Determining foraging locations. To determine the foraging locations of male emperors departing Auster in July we fitted 3 birds with satellite packs (platform transmitter terminals, PTTs: Model ST 6, Telonics Pty Ltd, USA) and tracked their movements. Each PTI was contained within a streamlined housing with a trailing antenna to reduce drag. The PTTs were attached by hose clamps and 'Loctite 401' adhesive to feathers on

the lower half. of the birds' backs. Each
Fig. 1. Mawson coast showing the locations of Auster and Taylor Glacier emperor penguin colonies, Mawson Station, topography of the sea bed (increasing darkness indicates greater depth), sea-ice conditions that prevailed between August and November 1993 and the path of a satellite-tracked male bird that departed Auster on 25 July. Dots on the penguins path represent $4 \mathrm{~d}$ intervals. The satellite pack failed on 27 August and the penguin returned to Auster on 8 September. In late November, a large section of the fast-ice east of Auster blew away (indicated by dashed line and arrows) exposing the contunental shelf $<50 \mathrm{~km}$ from the colony 
PTT weighed $450 \mathrm{~g}$ and had a frontal surface area of 14 $\mathrm{cm}^{2}(2.4 \%$ of the cross-sectional area of a $24 \mathrm{~kg}$ bird). The penguins' foraging locations after August were not investigated with PTTs, although some clues to the foraging grounds were inferred from the availability of open water and its proximity to the colonies (deduced from satellite images) and known distributions of the prey species

Foraging behaviour. The foraging behaviours of penguins from Auster were sampled with time-depth recorders (TDRs; Model Mk 5, Wildlife Computers, USA); these were fitted into streamlined housings and attached to the penguins' backs in a similar fashion as for the PTTs. The combined mass of a TDR, its housing and the hose clamps was $100 \mathrm{~g}$ and the units had frontal surface areas of $4 \mathrm{~cm}^{2} \quad(<1 \%$ of a penguin's cross-sectional area). TDRs were deployed on 14 males leaving the colony in July and August when chicks were newly hatched, 14 birds in September when chicks were crèche age, and 10 birds in October, about midway through the chick growing period. Robertson (1994) found that late in chick rearing up to $90 \%$ of birds abandon the colony, so to minimise device loss in our study TDRs were not deployed after October.

Males departing in July and August were expected to forage for approximately $3 w k$, whereas in September and October we anticipated trip durations of $<20 \mathrm{~d}$ (Robertson \& Newgrain 1996). To collect dive data for the entire trip periods, we staggered the start-up dates of the TDRs programable duty-cycles in July and August and September, but found this was unnecessary for the shorter September trips so in October we programmed the TDRs to start sampling when deployed. The TDRs recorded depths $>6 \mathrm{~m}$ at time intervals of 1, 2 or 5 s (usually 2). Generally, the TDRs sampled diving behaviour from single foraging trips but occasionally we obtained data from the same bird on consecutive trips to sea.

We processed the dive data with software provided by the manufacturer (zero-offset-correction and dive analysis software). Dives to maximum depths of $<10 \mathrm{~m}$ were ignored due to drift in the accuracy of the TDRs' pressure sensors (see Kirkwood \& Robertson 1997a). Dives to depths $>10 \mathrm{~m}$ were categorised by visual inspection of their profiles into non-foraging or foraging dives. During non-foraging dives, the penguins descended then ascended smoothly in short ( $<30$ s duration), shallow (usually to $<20 \mathrm{~m}$ but occasionally to $50 \mathrm{~m}$ depth) profiles that often were performed in a series. The penguins presumably performed these dives when commuting through the water between foraging sites or recovering from feeding dives, or for social and self-maintenance purposes (e.g. grooming).
Foraging dives were defined as either search dives or feeding dives. Search dives (or perhaps navigation dives) appeared similar in profile to the non-foraging dives but were longer ( 0.5 to 8.0 min duration), deeper (50 to $400 \mathrm{~m}$ depth) and typically singular Because there were no irregularities in the smooth descents and ascents of search dives to indicate prey were caught, we did not include them in the analysis of feeding depths. Feeding dives were performed to any depth; the penguins descended then performed either a period of depth fluctuations (possibly indicating prey pursuit) or remained at one depth (perhaps indicative of benthic foraging) and then ascended to the surface. On shallow feeding dives, depth fluctuations indicative of prey pursuit often were performed during the ascent. We compared the diving behaviours of penguins foraging in the same month and the diving patterns of penguins foraging during different months.

Dietary composition. We sampled the diets of Auster and Taylor Glacier penguins on 7 and 2 occasions respectively, by stomach flushing birds (Wilson 1984) as they returned to their colony. A total of 121 penguins were stomach flushed, 94 from Auster and 27 from Taylor Glacier, with a minimum of 12 penguins flushed on each sampling occasion. The flushing procedure for each penguin was repeated until clear water was expelled, usually after 2 or 3 flushes. To ensure the stomach had been emptied, we also manipulated the penguin's abdomen by hand. The stomach contents were drained in a $0.5 \mathrm{~mm}$ sieve to remove excess water and stored frozen for later analysis.

In the laboratory, the stomach content samples were defrosted and re-drained by lightly pressing them by hand into a $5 \mathrm{~mm}$ sieve, which gave a consistency in wetness among the samples. Each sample was weighed to $\pm 0.1 \mathrm{~g}$ (wet weight) and a representative $300 \mathrm{~g}$ subsample was extracted. Each subsample was placed in a plastic dish, then irrigated and panned up to 20 times to expose fish otoliths and jaws, squid beaks, and crustacean eyes. The number of fish otoliths in each subsample divided by 2 gave an estimate of fish numbers; counts of non-eroded lower beaks plus unpaired, but non-eroded, upper beaks provided an estimate of the squid numbers. The number of crustacean eyes divided by 2 gave an estimate of crustacean numbers. Fish masses were predicted from equations that correlated fish otolith or jaw lengths to fish mass (Williams \& McEldowney 1990, R. Williams unpubl data). When possible we estimated fish sizes and masses from jaws rather than otoliths, since otoliths of different sizes erode at different rates (Jobling \& Brieby 1986, Van Heezik \& Seddon 1989). Squid masses were predicted from lower-rostral-beak lengths (Clarke 1986, Adams 1990, Rodhouse et al. 1990, Lu \& Williams 1994). Euphausiids were too 
digested to measure so we assumed the mass of each Euphausia superba (Antarctic krill) and E. crystallorophias to be $0.60 \mathrm{~g}$ and $0.11 \mathrm{~g}$ respectively, these being the mean masses of individuals (excluding gravid females) caught during trawling on the Mawson Coast in January 1993 (G. Hosie pers comm.). Amphipods and decapods were minor components and were sufficiently intact to weigh directly. A quantitative measure of the diet composition was obtained by combining the masses of the various prey that were represented in the $300 \mathrm{~g}$ subsamples.

To develop the comparative quantification of the different prey types, we made several assumptions about the relative digestion rates acting upon them in the penguins' stomachs. Previous researchers (e.g Klages 1989), when assessing the diets of emperor penguins immediately after foraging, estimated fish, squid, and krill numbers from only pristine otoliths, beaks, and eyeballs, respectively. In our case, we sampled from penguins that had fasted for 2 to $8 \mathrm{~d}$ while walking across the fast-ice to the colony. Although the penguins potentially delayed digestion to retain food to feed their chicks, there was probably some digestion/erosion of recognisable prey fragments during the penguins' journey. We included all recognisable otoliths, because to have counted only pristine otoliths, which are composed of calcium carbonate and dissolve rapidly in seabird stomachs (Duffy \& Laurenson 1983), may have underestimated the contribution of fish to the penguins' diet. Squid beaks are chitinous and may remain in an almost pristine condition in a penguin's stomach for several weeks (Pütz 1995); hence, we considered only pristine beaks in our quantification of the squid proportion of the diet. Although krill eyes are also largely chitinous, the radules that comprise the outer surface of the eyes are bound together by proteins that may digest rapidly in the penguins' stomachs (G. Hosie pers. comm.). Moreover, the eyes are soft internally and may readily burst in the penguins' stomachs; we rarely sighted intact eyes in our samples. We therefore counted all krill eyes to quantify the krills' contribution to the diet mix. In summary, the estimates of prey composition assumed all recognisable otoliths, non-eroded squid beaks, and all krill eyes remained in the penguins' stomachs for a similar period.

Estimating prey consumption rates. We estimated the prey consumption rates of between 20 and 23 penguins on 5 occasions, based on the turnover rates of tritiated water $\left[{ }^{3} \mathrm{H}_{2} \mathrm{O}\right]$ and Eq. (4) of Nagy \& Costa (1980). Departing penguins were injected intra-muscularly with $1 \mathrm{ml}$ of distilled water containing 30 or $40 \mathrm{mCi}$ of tritium (HTO), bled ( $2 \mathrm{ml}$ from the radial vein) after a $2 \mathrm{~h}$ isotope equilibration period, and released. When each tritiated penguin returned to the colony it was caught and re-bled. All blood samples were stored frozen and returned to the laboratory, where aliquots of water were extracted from them by vacuum sublimation (Vaughan \& Boling 1961) and assayed for radioactivity in a liquid scintillation counter. The penguins' body-water pools were estimated from levels of HTO in the blood prior to foraging and rates of water intake during foraging were estimated from the dilution of the HTO between the pre-and post-foraging samples. Water intake rates were increased by $7 \%$ to compensate for the degree by which the HTO technique underestimates dietary water consumption (Kirkwood \& Robertson 1997b) and decreased by $2.4 \mathrm{ml} \mathrm{kg}^{-1}$ of body mass $\mathrm{d}^{-1}$ to account for incidental seawater intake (Robertson \& Newgrain 1992). Emperor penguins occasionally eat snow at the colony (pers. obs.) and may do so at the ice-edge, but we have no measure of the quantities consumed. Therefore, in initial calculations of prey consumption rates, we provided for a hypothetical intake of $100 \mathrm{ml}$ water $\mathrm{d}^{-1}$ consumed as snow, which is probably excessive given the aerated nature of snow eaten by penguins and the volume necessary to yield the hypothetical amount. The $100 \mathrm{ml} \mathrm{d}^{-1}$ hypothetical value decreased the estimated rates of prey consumption by just $0.2 \mathrm{~kg} \mathrm{~d}^{-1}(<5 \%)$. Considering the large volumes of snow required to dramatically alter the prey consumption estimates, and our inability to accurately quantify the snow intake, we ignored snow consumption in the calculations of prey consumption. Because the birds gained mass while away, and because water stored during the isotope integration period is not labelled with HTO, we subtracted the estimated nonlabelled water from the total water intake for each penguin. To do this, we assumed that each penguin's mass gain (mass change minus mass of stomach contents) was fat and that fat yields $1.07 \mathrm{ml}$ water $\mathrm{g}^{-1}$ when metabolised (Schmidt-Nielsen 1975).

The penguins' water intake rates were converted to prey consumption rates by dividing water intake by the mean water content of the prey in the birds' diet mix. For this calculation, we assumed the total water (free plus metabolic) in fish, squid and crustacea was $0.85,0.88$ and $0.87 \mathrm{ml} \mathrm{g}^{-1}$, respectively (Kirkwood \& Robertson 1997a). We determined the penguins' metabolisable energy intakes from their prey consumption rates, incorporating the energy density of their diet (determined from bomb calorimetry of the stomach contents) and the efficiency by which emperor penguins assimilate energy from fish, squid and krill $(81.8,76.2$ and $70.5 \%$ respectively; Robertson \& Newgrain 1992, Kirkwood \& Robertson 1997b).

Unlike other penguin species that may enter the water and feed as soon as they leave the colony, emperor penguins raising chicks must travel over the 
sea-ice for several days before reaching open water. To assess prey consumption and metabolic rates per foraging day, we subtracted the number of over-ice travel days from the number of days spent away from the colony. The travel days were recorded by the TDRs deployed between August and October, but after October, when TDR deployments ceased, the non-foraging days were estimated. These estimates took into account the overall trip durations, changes in the seaice conditions, increasing day-length and escalating food requirements of the chicks, which presumably stimulated faster rates of travel by parents. Finally, while commuting the penguins would have metabolised body tissue, released water and diluted the HTO in body water pools. We estimated the amount of water released by assuming the net specific cost of transport by a 23 to $30 \mathrm{~kg}$ emperor penguin was $17.5 \mathrm{~J} \mathrm{~kg}^{-1} \mathrm{~m}^{-1}$ (Dewasmes et al. 1980) and by determining the distance travelled to and from the ice-edge from satellite images of the Mawson Coast. The estimated metabolic water released was subtracted from each penguin's total water intake prior to the calculation of prey consumption per foraging day.

Foraging trip durations. In July and August 25 female and 32 male penguins at Auster and 6 female and 24 male penguins at Taylor Glacier were fitted with VHF transmitters $(80 \mathrm{~g}$ mass, $0.6 \%$ of the penguin's frontal area). The attendance times and foraging trip durations of these penguins were monitored by scanning radio receivers that were connected to data loggers (Advanced Telemetry Systems, Minnesota, USA), powered by solar panels, and deployed at both colonies. The receivers scanned each transmitter frequency for two $10 \mathrm{~s}$ periods every $4 \mathrm{~h}$. The system operated at Auster between July and early December and at Taylor Glacier between mid-September and late November.

At Auster, to augment the attendance data from the receiver, we patrolled the colony on foot on a neardaily basis and recorded the attendance of any penguins bearing plumage dye. This included all the birds we handled in other experiments and all birds carrying the radio transmitters. The reliability of these checks as a means of recording the presence of a marked penguin varied through the year. In July and August, the penguins were brooding small chicks and often huddled, which made resightings difficult. This difficulty was counteracted to some extent by the longer attendance times of the adults at this time of year which provided more opportunities for resighting. Between September and early November the birds were dispersed and remained at the colony for several days on each visit. We feel that over this period marked birds rarely would have passed through the colony without being sighted. In late November and early December many penguins visited the colony for less than a day (taking as few as $4 \mathrm{~h}$ in one instance to find a chick, feed it and leave). We often patrolled the colony twice per day at this time, but birds may still have entered and departed between our checks.

Analyses. Means are presented \pm 1 standard deviation. The differences between the means of samples in series were tested with pairwise Bonferroni comparisons after either nested or un-nested analysis of variance (ANOVA), and F-ratio tests for homogeneity of the variances. Significance was tested to the 0.05 level. To compare variables between sampling occasions and colonies, we calculated the means of non-parametric data (e.g. frequency of dive durations, which had skewed distributions) for ease of comparison between data sets.

\section{RESULTS}

\section{Body masses and mass gains}

The mean body masses of emperor penguins departing Auster increased from $22.9 \pm 1.7 \mathrm{~kg}$ ( $\mathrm{n}=40$ birds) in early September to $24.7 \pm 1.3 \mathrm{~kg}(\mathrm{n}=20)$ in November (ANOVA. $F_{4,137}=5.56, \mathrm{p}<0.001$ ). The male penguins leaving in August after their long winter fasts had body masses that averaged $23.5 \pm 1.2 \mathrm{~kg}(\mathrm{n}=30)$. On return to the colony, these males had gained $4.1 \pm 1.9 \mathrm{~kg}$ ( $\mathrm{n}=$ 6). All birds in this sample carried TDRs which might have reduced their ability to gain mass. Uninstrumented penguins foraging later in the year gained 4.0 $\pm 1.7 \mathrm{~kg}$ (range -0.5 to $+8.0 \mathrm{~kg}, \mathrm{n}=30$ ). There was no indication of a decrease in mass gained per trip as the seasons progressed (ANOVA for uninstrumented birds: $F_{4,31}=0.54, \mathrm{p}=0.71$ ) despite trip durations gradually decreasing (see below).

\section{Foraging location}

One PTT functioned for $64 \mathrm{~d}$ ( $72 \%$ of trip length) but the remaining 2 PTTs failed after 4 to $8 \mathrm{~d}$. After departing Auster in late July the tracked penguin travelled in a northeasterly direction taking about $7 \mathrm{~d}$ to cross the $60 \mathrm{~km}$ of fast-ice to the ice-edge (Fig. 1). At the time the ice-edge lay over the continental slope and was flanked by a 10 to $20 \mathrm{~km}$ wide polynya that separated the edge of the fast-ice from pack-ice regions to the north. The tracked bird foraged in this polynya for at least $25 \mathrm{~d}$, at which time the PTT failed, then returned to the colony $13 \mathrm{~d}$ later.

The fast-ice along the Mawson Coast remained stable until late November when large sections of ice east of Auster broke away (see Fig. 1). This break-out 
reduced the distance the penguins had to travel to reach open water to $<50 \mathrm{~km}$

\section{Diving behaviour}

We recovered all but 1 of the dive-recorders and retrieved data for 13,14 and 10 penguins foraging in August, September and October, respectively. The duration of travel between the colony and the ice-edge decreased from 3-10 d in July and August to 2-5 d in September and $2-3 \mathrm{~d}$ in October (Table 1 ). In all 3 periods the penguins averaged 10 to $12 \mathrm{~d}$ at sea (range 5 to 19 d) with the greatest variation between individuals occurring in September $(12.0 \pm 5.3 \mathrm{~d})$. The TDRs recorded data for 90,88 and $66 \mathrm{~d}$ at sea for the 3 periods, respectively.

While at sea, the penguins foraged daily, customarily entering the water around dawn and exiting at a range of times but mostly prior to dusk (Fig. 2). No complete rest days were recorded although the birds took rest periods, remaining out of the water between bouts of swimming on $10.6,10.5$ and $63.6 \%$ of days recorded during August, September and October, respectively. Of the penguins carrying TDRs, 41, 64 and 100\% took rest periods during the 3 mo, respectively. Usually 1 , but up to 3 , rest periods were taken in a single day with the mean duration of each rest period increasing between August and October from $1.6 \pm 0.7 \mathrm{~h}(\mathrm{n}=10 \mathrm{~d}$, range 1 to $3 \mathrm{~h})$ to $2.9 \pm 2.1 \mathrm{~h}(\mathrm{n}=61$, range 0.5 to $10 \mathrm{~h})$,

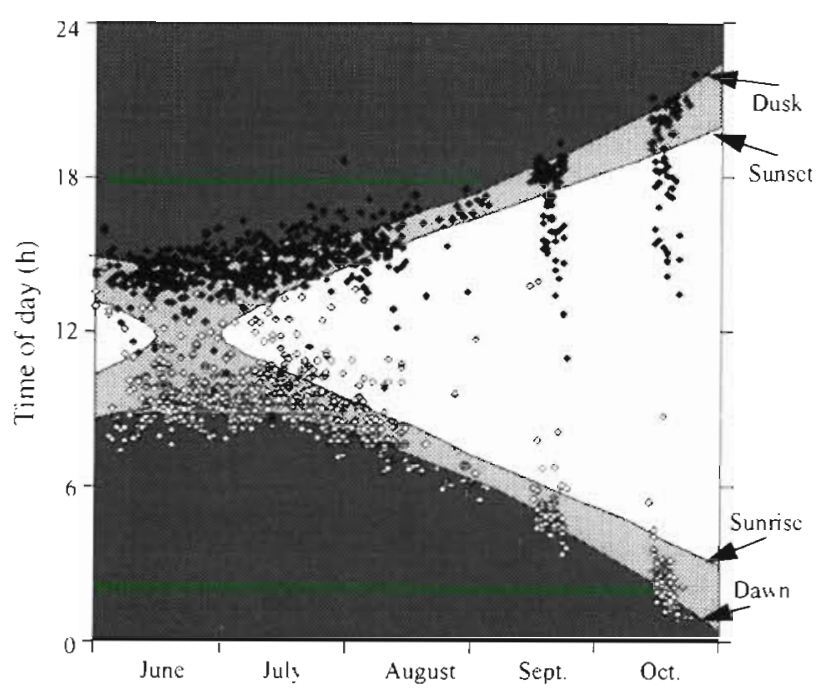

Fig. 2. Aptenodytes forsteri. Water-entry $(\diamond)$ and water-exit $(\bullet)$ times of emperor penguins foraging along the Mawson Coast in 1993 (includes winter data from Kirkwood \& Robertson 1997a) as well as local dawn/dusk and sunrise/sunset times (local solar time); dawn and dusk occurred when the sun was $3^{\circ}$ below the horizon although this increase was not statistically significant (ANOVA: $F_{282}=2.95, p=0.06$ ). Penguins taking rest periods late in the day and not re-entering the water before nightfall may account for the broad spread of water exit times in September and October (see Fig. 2).

Despite the increased frequency of rest periods over time, the penguins' daily swimming time increased from $7.83 \pm 1.50 \mathrm{~h}$ in August, to $12.23 \pm 1.25 \mathrm{~h}$ in September, and $12.95 \pm 1.24 \mathrm{~h}$ in October (Table 1). The swim time, as a proportion of time at the ice-edge, rose from 32.7 to 51.2 and $55.1 \%$, respectively, in these months (Table 1). Accordingly, the penguins' dive rate increased from $92.7 \pm 28.5$ dives $d^{-1}$ in August to 149.4 \pm 23.4 dives $d^{-1}$ in September, and $161.6 \pm 19.3$ dives $\mathrm{d}^{-1}$ in October. In addition, both the proportion of dives classed as feeding dives $(56,61$ and $62 \%$, respectively) and the hourly rate of feeding dives $(6.5,7.4$ and 7.7 dives $h^{-1}$, respectively) increased over the same months (Table 1). As a result, the penguins' frequency of feeding dives increased from $51.7 \pm 15.2$ to $90.5 \pm$ 15.3 and $100.8 \pm 12.6$ dives $\mathrm{d}^{-1}$, respectively.

Immediately after dawn the penguins foraged at shallow depths (typically $<100 \mathrm{~m}$; Fig. 3). As the day progressed, however, the range of foraging depths increased, peaking around midday when depths $>400 \mathrm{~m}$ were occasionally attained; dive depth then decreased toward evening.

During August and September the majority of birds foraged mainly at depths $<100 \mathrm{~m}$, although the feeding depths of individuals varied considerably. For example, in September one penguin hunted at depths between 100 and $200 \mathrm{~m}$ on $70 \%$ of its feeding dives and another penguin hunted prey deeper than $300 \mathrm{~m}$ on $31 \%$ of its dives. There was less individual variation in dive depth during October than in August or September with all but 1 of the birds targeting prey primarily between 20 and $50 \mathrm{~m}(37$ to $59 \%$ of feeding dives). There was distinctly less feeding below $100 \mathrm{~m}$ depth in October ( $23 \%$ of dives) than there had been in August and September (44 and $46 \%$ of dives respectively; $37 \%$ of dives during the 3 mo combined; Fig. 3 ). Penguins for which dive records were obtained on consecutive foraging trips tended to reduce their frequency of dives to depths $>100 \mathrm{~m}$ on their second trip.

The maximum dive depths and maximum dive durations achieved by the penguins did not vary significantly between months and averaged $330.2 \pm 66.7 \mathrm{~m}$ and $9.48 \pm 1.85 \mathrm{~min}$, respectively (see Table 1). Mean foraging dive durations were significantly longer in September $(4.31 \pm 1.53 \mathrm{~min})$ than August $(3.87 \pm$ $1.55 \mathrm{~min})$ or October $(3.70 \pm 1.53 \mathrm{~min}$; nested ANOVA: $F_{2.34}=45.7, p<0.001$ ) which probably reflected the frequent deep diving by some penguins in September and the fact that deep dives tended to last Ionger than shallow dives (Fig. 3). 
Table 1. Aptenodytes forsteri. Foraging behaviour of emperor penguins as determined from time-depth recorders (TDRs). $\mathrm{n}=\mathrm{number}$ of penguins except for the mean duration of rest periods where $\mathrm{n}=$ number of rest periods. Depth ratio: percentage of feeding dives to within the depth ranges shown; duration ratio: percentage of foraging dives with duration within the ranges shown

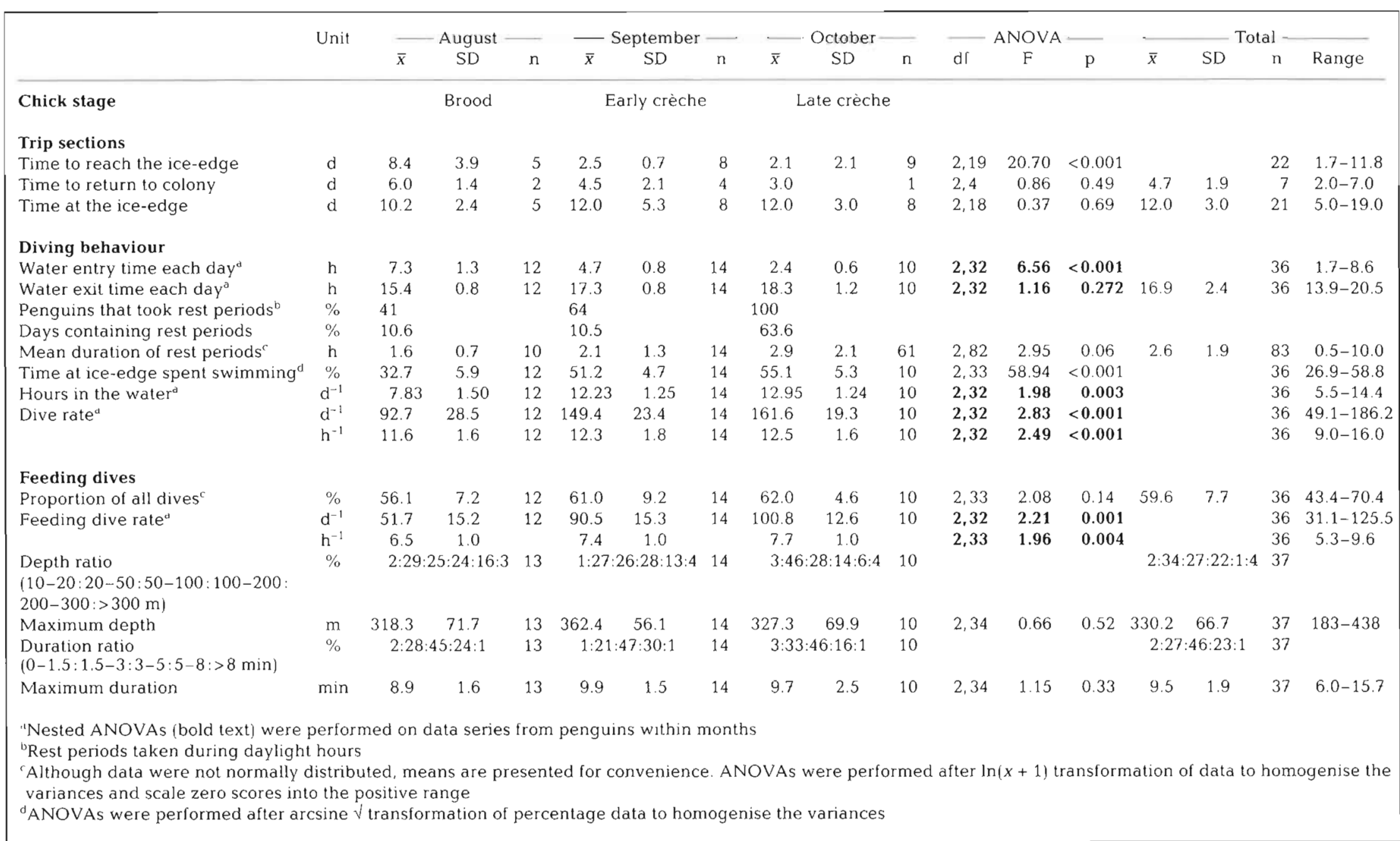




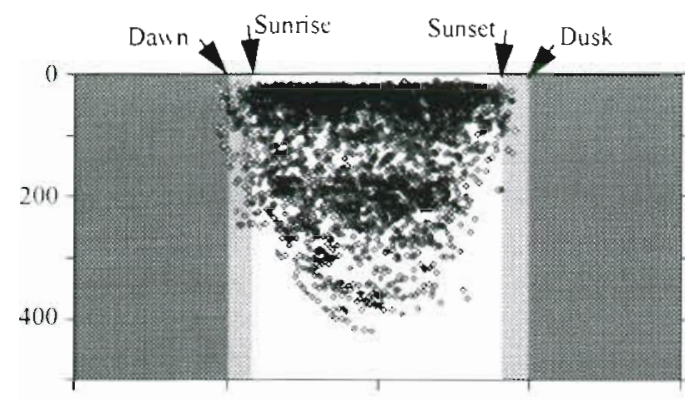

August

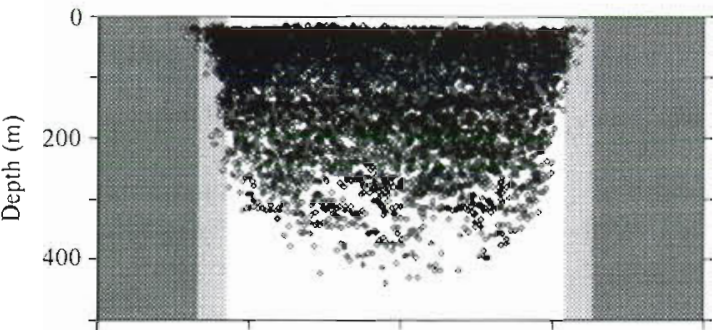

September

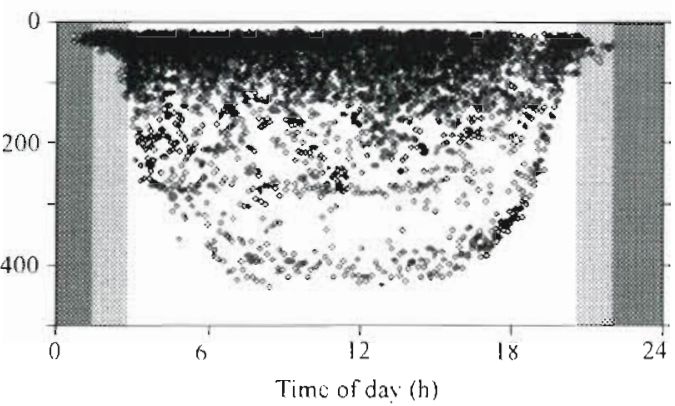

October

6095 dives 10 penguins

Fig. 3. Aptenodytes forsteri. Depth of feeding dives relative to time of day (local solar time) recorded for emperor penguins from Auster colony in August, September and October 1993. Times of dawn, sunrise, sunset and dusk are for the longest day of each month. Darker shading represents night-time, lighter shading represents twilight and no shading represents daytime

\section{Dietary composition}

The body masses of penguins' stomachs flushed on their return from foraging trips were similar between sampling dates and averaged $29.2 \pm 2.2 \mathrm{~kg}$ (ANOVA. $\left.F_{8,118}=0.92, p=0.5\right)$. The wet food mass in the birds' stomachs varied seasonally (ANOVA: $F_{8,112}=4.94, \mathrm{p}<$ $0.001)$, being lowest at Taylor Glacier in September $(0.9 \pm 0.6 \mathrm{~kg}, \mathrm{n}=15)$ and highest at Auster in early October $(2.0 \pm 0.5 \mathrm{~kg}, \mathrm{n}=12$; Table 2$)$. On average, each penguin yielded $1.3 \pm 0.6 \mathrm{~kg}$ of food $(\mathrm{n}=121$, range 0.3 to $2.5 \mathrm{~kg}$ ). Gastric stones were recovered from $90 \%$ of those penguins flushed.

Data on the relative proportions of prey types in the diet mix, water and energy contents of the prey and the penguins' predicted dietary assimilation efficiencies that were incorporated into the calculations of prey consumption rates are shown in Table 2.

Recognisable fragments of fish, squid and crustacea were present in 96,60 and $88 \%$, respectively, of the Auster samples $(n=94)$ and in 93,59 and $100 \%$ of the Taylor Glacier samples ( $\mathrm{n}=27$ ). Of the 24 prey taxa identified to species 15 were fish, 4 were squid and 5 were crustaceans (Table 3 ).

The fish component of the penguins' diet on all sampling occasions was dominated numerically by Antarctic silverfish Pleuragramma antarcticum, although at times Notolepis coatsi, Pagothenia borchgrevinki or a Trematomus species contributed more to the diets by mass (Fig. 4). A myctophid, Electrona antarctica, was common in late October and early November samples from Auster, although its otoliths were highly eroded. $P$. antarcticum and $N$. coatsi were the only fish species present on all sampling occasions and the only fish

Table 2. Aptenodytes forsteri. Mean wet mass of stomach contents flushed from emperor penguins returning to Auster and Taylor Glacier colonies during 1993, prey components determined from the stomach contents as a percentage by mass, water and energy content of the prey and the calculated efficiency by which the penguins could assimilate the diet mix. Water content: free plus metabolic water content calculated assuming the water contents of fish, squid and krill were $0.85,0.88$ and $0.87 \mathrm{ml} \mathrm{g}^{-1}$, respectively (Kirkwood \& Robertson 1997a). Energy content determined by bomb calorimetry of stomach contents. Overall dietary assimilation efficiency calculated assuming the proportions $81.8,76.2$ and 70.5 of fish, squid and krill, respectively, could be assimilated (see Robertson \& Newgrain 1992, Kirkwood \& Robertson 1997b)

\begin{tabular}{|c|c|c|c|c|c|c|c|c|}
\hline \multirow[t]{2}{*}{ Date } & \multirow[t]{2}{*}{ Colony } & \multirow{2}{*}{$\begin{array}{l}\text { Mean mass } \\
\text { of stomach } \\
\text { contents (g) }\end{array}$} & \multicolumn{3}{|c|}{ Diet mix $(\%)$} & \multirow{2}{*}{$\begin{array}{c}\text { Water } \\
\text { content } \\
(\%)\end{array}$} & \multirow{2}{*}{$\begin{array}{l}\text { Energy } \\
\text { content } \\
\left(\mathrm{kJ} \mathrm{g}^{-1}\right)\end{array}$} & \multirow{2}{*}{$\begin{array}{c}\text { Assimilation } \\
\text { efficiency } \\
(\%)\end{array}$} \\
\hline & & & Fish & Squid & Krill & & & \\
\hline 23 Aug & Auster & 1179.8 & 27.3 & 5.2 & 67.5 & 0.865 & 5.16 & 0.739 \\
\hline 15 Sep & Taylor & 911.6 & 28.3 & 6.0 & 65.7 & 0.865 & 5.11 & 0.740 \\
\hline 20 Sep & Auster & 1150.4 & 33.0 & 13.1 & 53.9 & 0.865 & 5.19 & 0.750 \\
\hline $11 \mathrm{Oct}$ & Auster & 1995.7 & 32.7 & 25.5 & 41.8 & 0.866 & 5.43 & 0.756 \\
\hline $25 \mathrm{Oct}$ & Auster & 1606.2 & 32.0 & 24.6 & 43.4 & 0.866 & 5.53 & 0.755 \\
\hline $5 \mathrm{Nov}$ & Taylor & 1336.3 & 10.9 & 58.3 & 30.8 & 0.874 & 5.19 & 0.751 \\
\hline 11 Nov & Auster & 1185.8 & 14.5 & 48.7 & 36.7 & 0.871 & 5.37 & 0.748 \\
\hline $25 \mathrm{Nov}$ & Auster & 1373.7 & 24.4 & 64.2 & 11.4 & 0.872 & 5.48 & 0.769 \\
\hline $3 \mathrm{Dec}$ & Auster & 1278.8 & 74.8 & 24.5 & 0.7 & 0.857 & 5.41 & 0.803 \\
\hline
\end{tabular}


Table 3. Aptenodytes forsteri. Summary of results from the analysis of prey represented in $300 \mathrm{~g}$ subsamples of emperor penguin stomach contents $(n=121)$ collected at Auster and Taylor Glacier colonies from August to December 1993. Individual prey: fish represented by otolith pairs, squid by lower-rostral beaks and crustacea by pairs of eyes. Non-erod.: fish and squid represented by non-eroded otoliths and beaks, respectively. Mass/item: see text for the source of individual prey masses. \% contribution: total mass of prey items and dietary contributions calculated from all fish, only non-eroded squid and all crustacea

\begin{tabular}{|c|c|c|c|c|c|c|c|c|}
\hline \multirow[t]{2}{*}{ Prey species } & \multicolumn{2}{|c|}{ Stomachs } & \multicolumn{4}{|c|}{$\longrightarrow$ Individual prey -} & \multicolumn{2}{|c|}{$\%$ contribution: } \\
\hline & $\mathrm{n}$ & $(\%)$ & $\begin{array}{c}\text { Total } \\
\text { (n) }\end{array}$ & $\begin{array}{l}\text { Non- } \\
\text { erod. (n) }\end{array}$ & $\begin{array}{c}\text { Mass/ } \\
\text { itern }(\mathrm{g})\end{array}$ & $\begin{array}{c}\text { Total } \\
\operatorname{mass}(g)\end{array}$ & $\begin{array}{c}\text { by } \\
\text { number }\end{array}$ & $\begin{array}{l}\text { by } \\
\text { mass }\end{array}$ \\
\hline \multicolumn{9}{|l|}{ Fish } \\
\hline \multicolumn{9}{|l|}{ Channychthydae } \\
\hline Chaenodraco wilsoni & 2 & $(2)$ & 2 & 1 & 185.1 & 370.2 & $<0.1$ & 0.8 \\
\hline Neopagetopsis ionah & 2 & (2) & 3 & 0 & 24.9 & 74.7 & $<0.1$ & 0.2 \\
\hline Pagetopsis macropterus & 1 & (1) & 1 & 1 & 24.9 & 24.9 & $<0.1$ & 0.1 \\
\hline Pagetopsis sp. & 3 & (2) & 4 & 1 & 47.6 & 190.2 & $<0.1$ & 0.4 \\
\hline Unidentified channichthyid & 11 & (9) & 19 & 0 & 32.0 & 607.2 & 0.1 & 1.3 \\
\hline \multicolumn{9}{|l|}{ Gempylidae } \\
\hline Paradiplospinus gracilis & 1 & (1) & 1 & 0 & 14.9 & 14.9 & $<0.0$ & $<0.0$ \\
\hline \multicolumn{9}{|l|}{ Myctophidae } \\
\hline Electrona antarctica & 13 & $(11)$ & 132 & 0 & 6.9 & 914.8 & 0.3 & 1.9 \\
\hline Krefftichthys anderssoni & 3 & (2) & 5 & 0 & 6.9 & 34.7 & $<0.1$ & 0.1 \\
\hline Gymnoscopelus braueri & 1 & (1) & 1 & 0 & 6.9 & 6.9 & $<0.1$ & $<0.1$ \\
\hline Unidentified myctophid & 1 & (1) & 4 & 0 & 6.9 & 27.7 & $<0.1$ & 0.1 \\
\hline \multicolumn{9}{|l|}{ Nototheniidae } \\
\hline Pleuragramma antarcticum & 90 & $(74)$ & 1516 & 57 & 2.0 & 3058.0 & 4.0 & 6.5 \\
\hline Pagothenia borchgrevinki & 3 & (2) & 14 & 1 & 140.3 & 1964.4 & $<0.1$ & 4.2 \\
\hline Trematomus bernachii & 1 & (1) & 2 & 0 & 85.9 & 171.8 & $<0.1$ & 0.4 \\
\hline T eulepidotus & 7 & $(6)$ & 16 & 3 & 84.3 & 1348.0 & $<0.1$ & 2.9 \\
\hline T. lepidorhinus & 2 & (2) & 5 & 2 & 135.3 & 676.7 & $<0.1$ & 1.4 \\
\hline T loennbergi & 1 & (1) & 1 & 0 & 127.3 & 127.3 & $<0.1$ & 0.3 \\
\hline T. newnesi & 1 & (1) & 11 & 0 & 52.4 & 576.4 & $<0.1$ & 1.2 \\
\hline Trematomus sp. & 7 & $(6)$ & 8 & 0 & 81.3 & 650.2 & $<0.1$ & 1.4 \\
\hline Unidentified nototheniid & 9 & (7) & 20 & 0 & 95.4 & 1907.8 & 0.1 & 4.0 \\
\hline \multicolumn{9}{|l|}{ Paralepidae } \\
\hline Notolepis coatsi & 35 & (29) & 143 & 9 & 5.5 & 788.3 & 0.4 & 1.7 \\
\hline Unidentified fish & 14 & $(12)$ & 25 & 0 & 10.0 & 250.0 & 0.1 & 0.5 \\
\hline Total & 115 & $(95)$ & 1933 & 75 & 7.1 & 13785.1 & 5.1 & 29.2 \\
\hline \multicolumn{9}{|l|}{ Cephalopods } \\
\hline Psychroteuthis glacialis & 63 & $(52)$ & 674 & 351 & 17.9 & 12056.4 & 0.9 & 25.6 \\
\hline Alluroteuthis antarcticus & 30 & (25) & 74 & 22 & 21.6 & 1595.3 & $<0.1$ & 3.4 \\
\hline Kondakovia longimana & 17 & (14) & 66 & 1 & 1.5 & 96.2 & $<0.1$ & 0.2 \\
\hline Gonatus antarcticus & 3 & (2) & 3 & 0 & 0.0 & 0.0 & $<0.1$ & $<0.1$ \\
\hline Batoteuthis sp. & 1 & (1) & 1 & 1 & 19.1 & 19.1 & $<0.1$ & $<0.1$ \\
\hline Total & 72 & $(60)$ & 818 & 375 & 16.8 & 13767.0 & 1.0 & 29.2 \\
\hline \multicolumn{9}{|l|}{ Crustacea } \\
\hline \multicolumn{9}{|l|}{ Euphausiacea } \\
\hline Euphausia superba & 107 & $(88)$ & 32052 & 0.6 & 19231.2 & 84.4 & 40.8 & \\
\hline E. chrystallorophias & 1 & (1) & 3582 & 0.1 & 394.0 & 9.4 & 0.8 & \\
\hline \multicolumn{9}{|l|}{ Amphipoda } \\
\hline Hyperia macrocephala & 7 & $(6)$ & 12 & 0.1 & 1.2 & $<0.1$ & $<0.1$ & \\
\hline Abyssorchomene rossi & 6 & (5) & 10 & 0.1 & 1.0 & $<0.1$ & $<0.1$ & \\
\hline Eusirus sp. & 5 & (4) & 7 & 0.1 & 0.7 & $<0.1$ & $<0.1$ & \\
\hline \multicolumn{9}{|l|}{ Decapoda } \\
\hline Notocrangon antarcticus & 2 & (2) & 2 & 0.8 & 1.6 & $<0.1$ & $<0.1$ & \\
\hline Total & 110 & (91) & 35662 & 0.6 & 19629.4 & 93.9 & 41.6 & \\
\hline Total overall & 121 & $(100)$ & 37970 & 1.2 & 47181.6 & & & \\
\hline
\end{tabular}




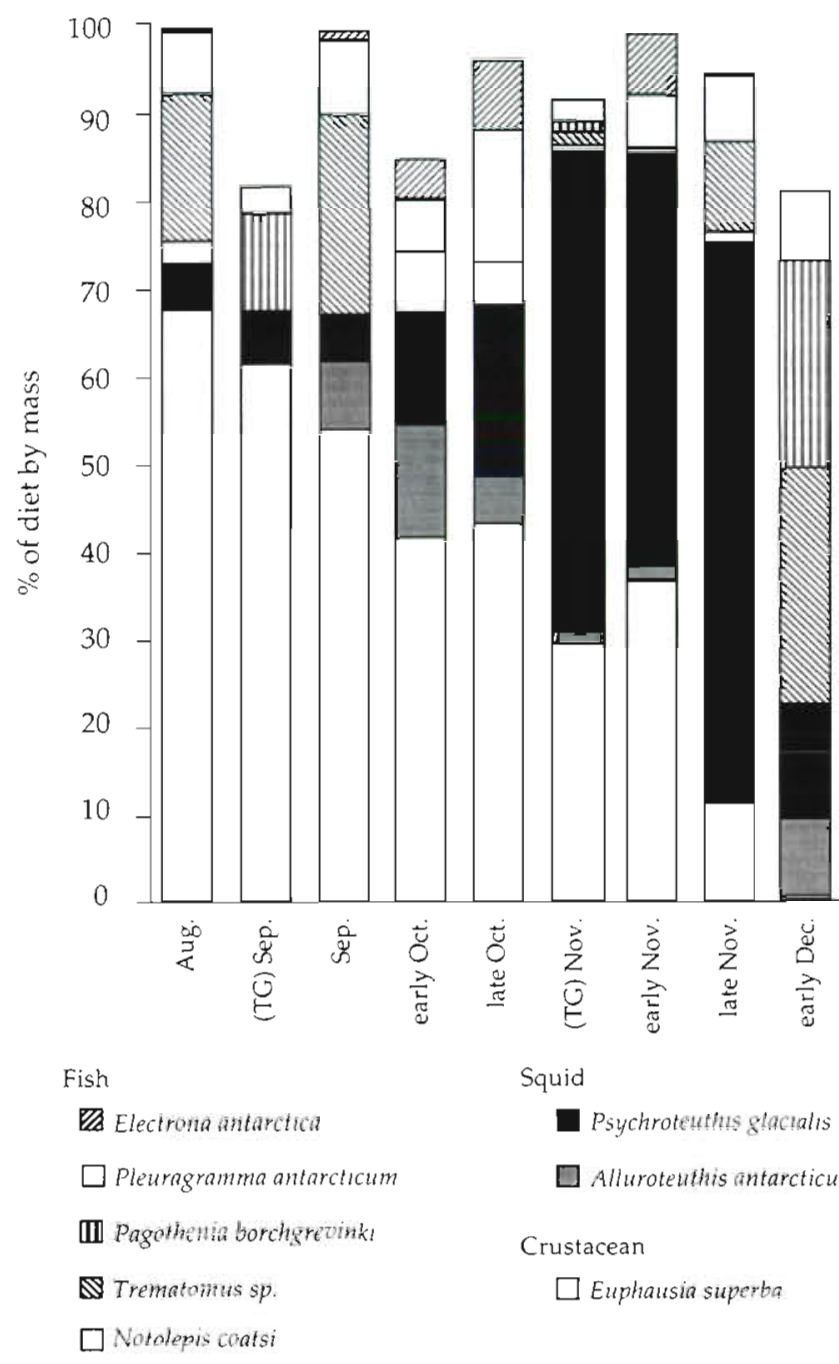

Fig. 4. Aptenodytes forsteri. Composition by mass of the main prey species in the diet of emperor penguins. Collections were made at Auster colony in all months and at Taylor Glacier colony (TG) in September and November

species for which sufficient numbers of non-eroded jaws were obtained to assess seasonal changes in size. The sizes of the $P$. antarcticum and $N$. coatsi taken, however, remained relatively constant through the year (Fig. 5a, b) and were small, averaging $2.1 \pm 1.4 \mathrm{~g}$ $\left(66 \pm 11 \mathrm{~mm}\right.$ standard length, $\left.\mathrm{SL}_{i} \mathrm{n}=367\right)$ and $4.4 \pm$ $2.1 \mathrm{~g}(178 \pm 37 \mathrm{~mm} \mathrm{SL}, \mathrm{n}=171)$, respectively.

The glacier squid Psychroteuthis glacialis dominated the squid component of the birds' diet on all but 2 occasions, the exceptions being at Auster in September and early October when fewer but larger (up to $500 \mathrm{~g}$ body mass) Alluroteuthis antarcticus contributed a greater mass to the diet. Beaks from the large, oceanic squid Kondakovia longimana were encountered but always were very eroded; hence, we ignored them in the interpretation of prey composition. The penguins con- sumed 2 size classes of P. glacialis large (>140 mm) individuals were taken in August and September but rarely thereafter, when the penguins fed almost exclusively on small squid that increased in size between August and December from $17.8 \pm 1.0 \mathrm{~g}$ mass $(96.9 \pm$ $1.2 \mathrm{~mm}$ mantle length, $\mathrm{n}=3)$ to $40.6 \pm 7.7 \mathrm{~g}(122.0 \pm$ $7.6 \mathrm{~mm}, \mathrm{n}=9$ sampling times; Fig. $5 \mathrm{c}$ ). On most sampling occasions, over $50 \%$ of the penguins we flushed had eaten small $P$. glacialis. A total of 71 non-eroded beaks was extracted from a single $300 \mathrm{~g}$ subsample collected at Auster in late November.

Antarctic krill dominated the crustacean component of the penguins' diet, but in September, 1 Taylor Glacier penguin yielded only Euphausia crystallorophias, this being our only observation of this prey in the samples. Other crustaceans consumed occasionally were the amphipods Hyperia macrocephala, Abyssorchomene rossi and Eusirus sp., and a decapod Notocrangon antarcticus.

Penguins at both colonies ate similar prey although Auster penguins tended to catch fewer crustaceans and more fish than did Taylor Glacier penguins. Antarctic krill dominated the diets at both colonies: $92 \%$ by number and $37 \%$ by mass at Auster, and $74 \%$ by number and $52 \%$ by mass at Taylor Glacier. The relative importance of krill decreased through time from $68 \%$ of the diet by mass in August, to $<1 \%$ in early December (Fig. 4). Overall, Psychroteuthis glacialis were the next most important dietary items by mass (26\% at Auster and $25 \%$ at Taylor Glacier) and were eaten most frequently in November ( 47 to $63 \%$ at Auster and $57 \%$ at Taylor Glacier). Other prey species contributed to the diets either regularly, as did Pleuragramma antarcticum $(7 \pm 4 \%$ of the diet by mass, range 3 to $15 \%, n=9$ sampling times), or irregularly, as did various Trematomus species $(9 \pm 11 \%$, range 0 to $27 \%)$, Alluroteuthis antarcticus $(4 \pm 5 \%$, range 0 to $13 \%)$ and Pagothenia borchgrevinki ( $4 \pm 8 \%$, range 0 to $24 \%$ ).

\section{Water intake and prey consumption rates}

Male penguins departing Auster in July and August had significantly lower body water pools than did penguins of both sexes departing later in the year (583.4 \pm $31.7 \mathrm{ml} \mathrm{kg}{ }^{-1}, \mathrm{n}=23$ vs $645.0 \pm 40.1 \mathrm{ml} \mathrm{kg}^{-1}, \mathrm{n}=83$ respectively; ANOVA: $\left.F_{4,101}=11.30, \mathrm{p}<0.001\right)$. The males probably were dehydrated after their long winter fasts. We determined water intake and prey consumption rates only for penguins caught and bled before they re-entered the colony and fed their chicks, which reduced our sample sizes to $4,18,11,12$ and 9 penguins that foraged during August, September, October, early November and late November, respec- 
a. Pleuragramma antarcticum $(n=367)$

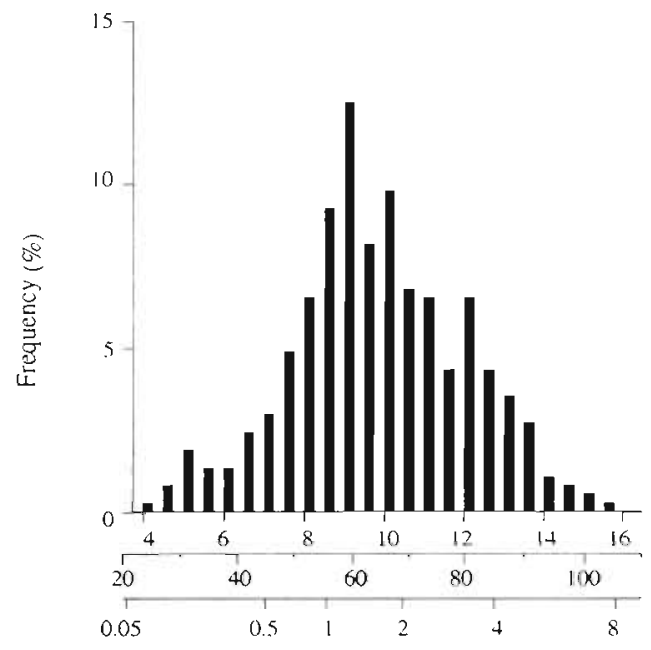

b. Notolepis coatsi $(n=171)$

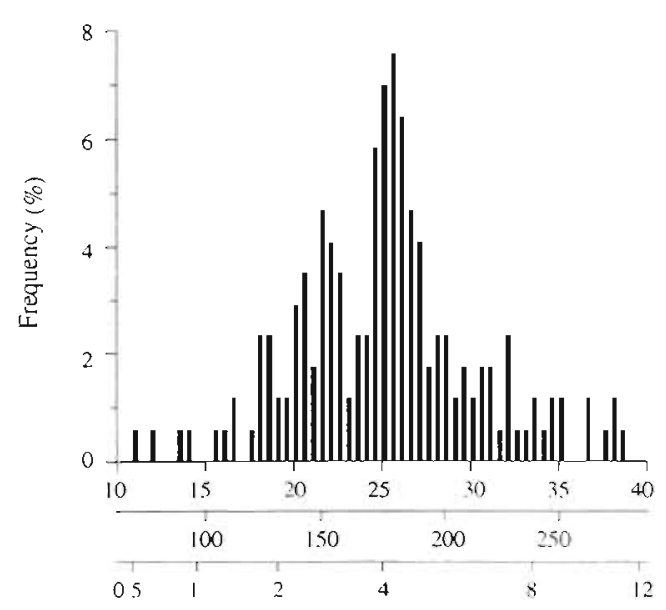

$\mathrm{JL}(\mathrm{nm})$

SL ( $\mathrm{mm})$

Mass (g)
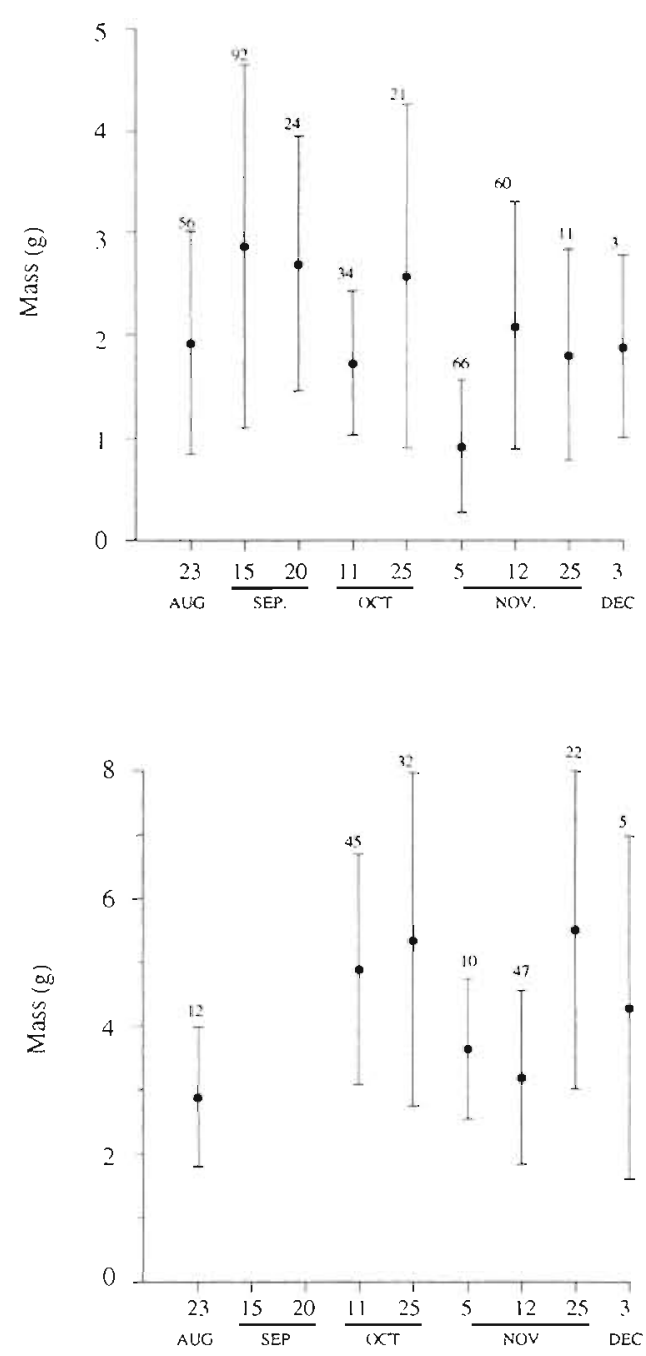

c. Psychroteuthis glacialis $(n=350)$

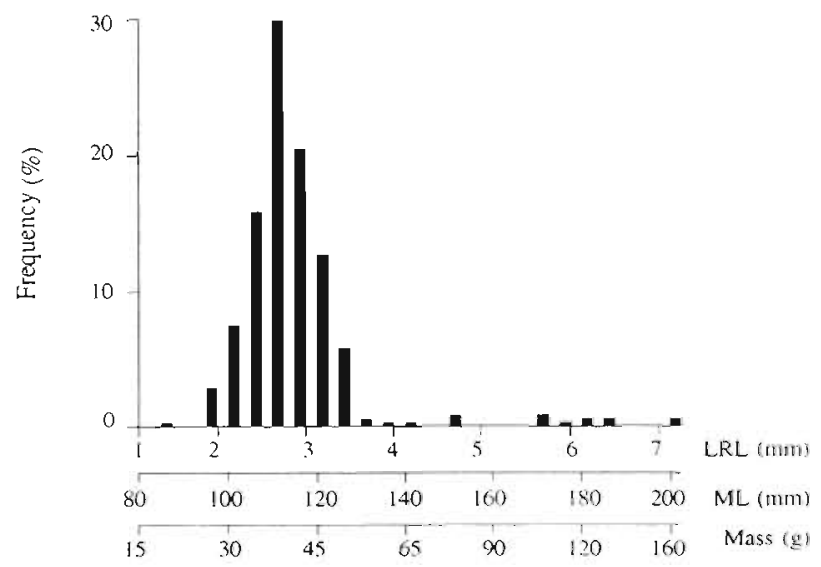

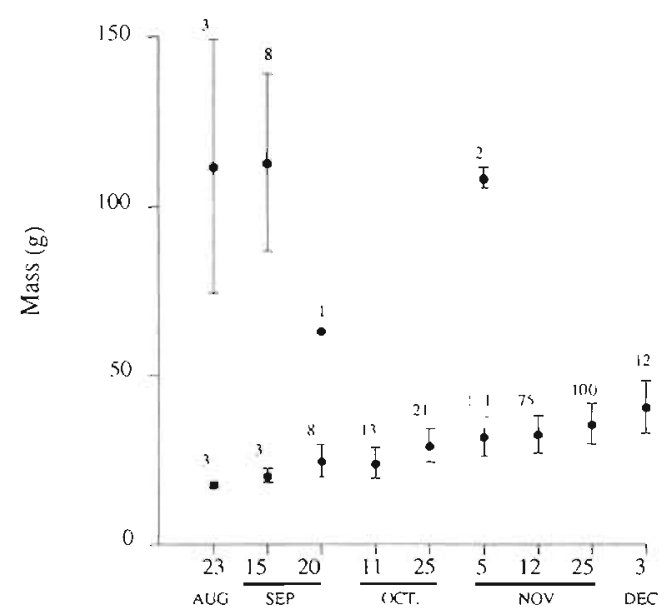

Fig. 5. Aptenodytes forsteri. Size-frequency distribution and changes in mean ( \pm SD) mass (error bars are capped by the number of penguins sampled) with time of (a) Pleuragramma antarcticum, (b) Notolepis coatsi and (c) Psychroteuthis glacialis eaten by emperor penguins. Note: the penguins ate $P$. glacialis from 2 distinct cohorts. JL: jaw length; SL: standard length; LRL: lowerrostral-beak length; ML: mantle length 
tively. The penguins' water intakes calculated per day away from the colony increased more than 2 -fold over the chick rearing period from $90.2 \pm 9.4 \mathrm{ml} \mathrm{kg}^{-1}$ during August to $222.2 \pm 34.7 \mathrm{mI} \mathrm{kg}^{-1}$ during late November (Table 4, Fig. 6). These rates were equivalent to the consumption of $2.6 \pm 0.2 \mathrm{~kg}$ and $6.8 \pm 1.0 \mathrm{~kg}$ of prey per day away from the colony, respectively.

The consumption rates per day away from the colony were converted to rates per foraging day after accounting for commuting days based on the TDR data. During August, September and October the mean number of days it took penguins to travel to or from the ice-edge were $4,3.5$ and 2.5 , respectively. We assumed the penguins took $2 \mathrm{~d}$ to travel to the ice-edge in early November and $1 \mathrm{~d}$ to cover the distance in late November, when the loss of fast-ice reduced the distance between the colony and the ice-edge from $80 \mathrm{~km}$ to $50 \mathrm{~km}$. Due to the reduced travel times, metabolic water released during travel (which was subtracted from total water turnover) declined from $2440 \mathrm{ml}$ in August to $1500 \mathrm{ml}$ in late November. Taking into account the adjustments, the penguins' estimated prey consumption rates per foraging day doubled from $4.0 \pm 1.0 \mathrm{~kg} \mathrm{~d}^{-1}$ during August to $8.7 \pm 1.7 \mathrm{~kg} \mathrm{~d}^{-1}$ in late November (Table 4, Fig. 6). These rates were equivalent to metabolisable energy intake rates of $628.0 \pm 133.9 \mathrm{~kJ}$ $\mathrm{kg}^{-1}$ and $1422.0 \pm 308.4 \mathrm{~kJ} \mathrm{~kg}^{-1}$ per foraging day, respectively.

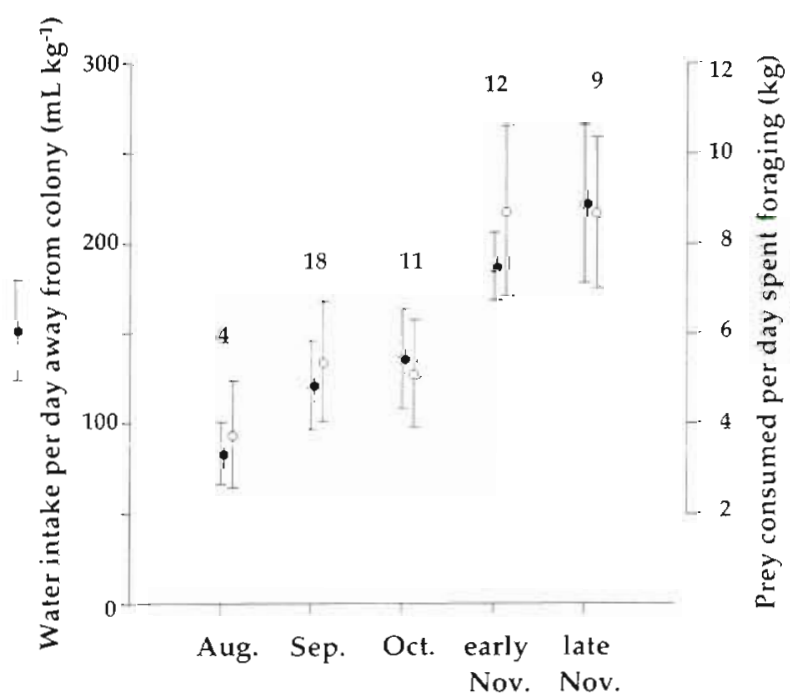

Fig. 6. Aptenodytes forsteri. Water intake per day away from the colony and prey consumption rates per foraging day of emperor penguins foraging during different months. Foraging days per trip were determined by TDRs during August, September and October, and estimated dunng November (see 'Materials and methods'). Data are means \pm SD and error bars are capped by the number of penguins sampled

\section{Foraging trip durations}

Data from the remote attendance receiver at Auster were incomplete because the colony expanded to several $\mathrm{km}^{2}$ in spring and encircled grounded icebergs which blocked the radio signals. We therefore relied on visual monitoring to obtain attendance records at this colony. Many of the birds we marked and monitored apparently did not continue to raise chicks, perhaps in response to our manipulation or the death of their chicks. These birds either remained at the colony for long periods without attending a chick or were sighted infrequently, indicating their colony attendance pattern was disrupted. We obtained regular cycling patterns for 9 females, 22 males and 26 birds of unknown sex between July-September and 7 December (Table 5). Although these birds had been handled for either plumage dyeing, attachment of devices, injecting with tritium or stomach flushing (or some combination of these), their cycling patterns were both regular and similar to each other; presumably the birds behaved normally on release. The females and males returned to the colony from foraging trips on $7.8 \pm 0.4$ and $7.4 \pm 0.5$ occasions, respectively (Table 5 ). As our field season ended about $1 \mathrm{wk}$ prior to the commencement of fledging (in mid-December), and the penguins cycle time was $<10 \mathrm{~d}$ at the time, the adults probably visited the colony at least once more after our departure. This additional visit would take the total number of foraging trips by females and males to about 9 and 8 . respectively, during the 5 mo period of chick development.

At Taylor Glacier, the remote attendance receiver never detected 7 of the deployed transmitters and we suspect these units were poorly attached and lost at sea. A further 12 birds were detected infrequently due to either malfunctions with the equipment or disruption to the birds' normal chick rearing behaviour. Frequent and regular cycling patterns were recorded for 3 females and 8 males (Table 5). Between mid-September and late November all but 1 penguin made 4 visits to the colony; the anomalous bird, a male, made 7 visits. Over the same time period Auster penguins also averaged 4 visits to the colony. The similar frequency of foraging trips between birds from the 2 colonies suggests trip durations and attendance frequencies are not the reason for the disparity in sizes between the colonies, Taylor Glacier containing 70\% fewer breeders than Auster.

Female emperors returning to Auster at hatching in July and August brooded their chicks for $18.8 \pm 5.5 \mathrm{~d}$, the reciprocal of which was the duration of the fastbreaking trip of the males (17.7 $\pm 3.8 \mathrm{~d}$; Table 5, Fig. 7). The females then departed and foraged at sea for $8.7 \pm$ $2.7 \mathrm{~d}$ which was similar to the period of chick brooding 


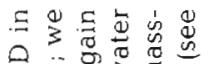

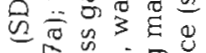

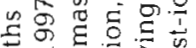

至

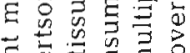

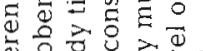

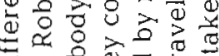

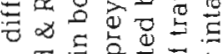

$\Xi \begin{gathered}0 \\ 8\end{gathered}$

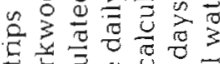

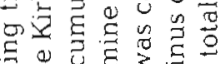

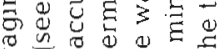

은

을

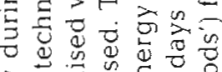

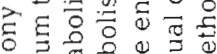

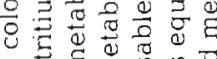

包是

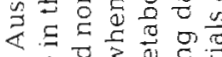

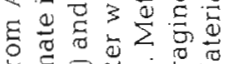

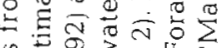

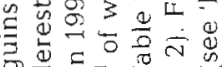

कृ

¿

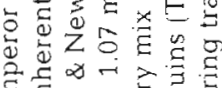

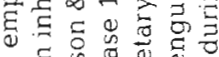

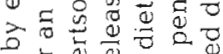

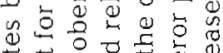

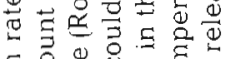

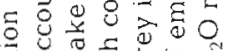

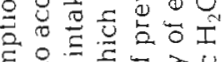

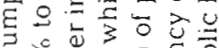

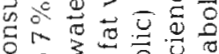

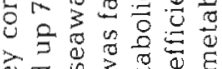

बें

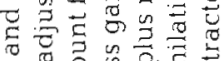

\%

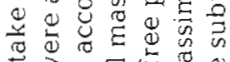

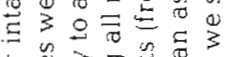

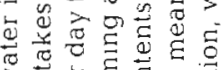

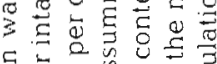

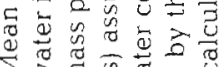

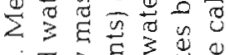

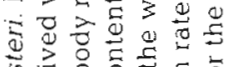

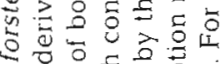

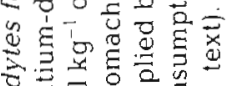

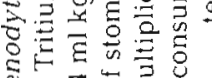

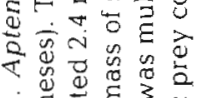

ナ)

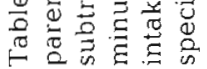

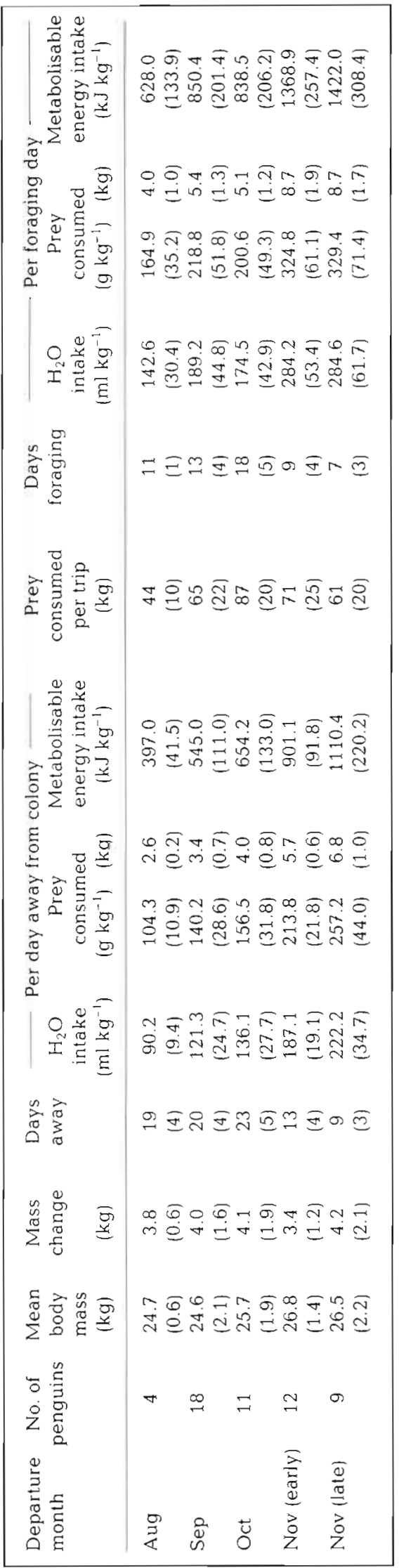

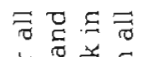

战造

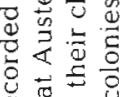

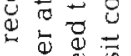

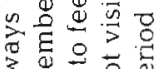

3.

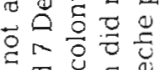

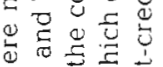

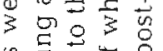

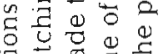

든

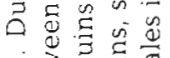

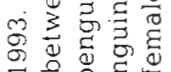

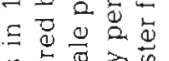

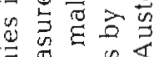

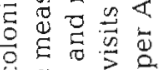

पे

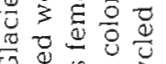

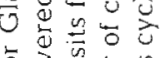

$\frac{0}{2} \geq \frac{5}{5}$

ते

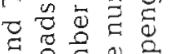

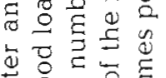

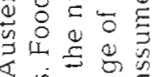

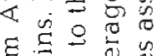

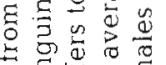

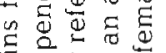

言焉里

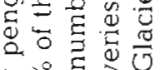

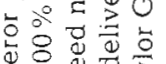

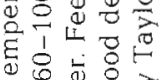

일

50

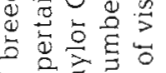

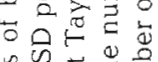

बैं क्षे

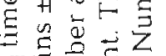

व है है

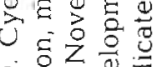

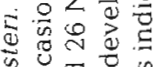

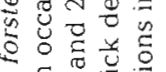

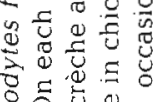

造语票

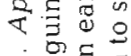

的宫宓

告要造

\begin{tabular}{|c|c|c|c|c|c|c|}
\hline 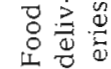 & $\stackrel{\infty}{\infty}$ & $\begin{array}{l}\pi 0 \\
\approx 0\end{array}$ & $\begin{array}{ll}\infty \\
\infty\end{array}$ & $\because: 0$ & $\ddot{\theta}=$ & \\
\hline$u$ & & & $\because 0$ & & $\begin{array}{l}\infty \\
0 \\
0\end{array}$ & $\sum_{\sigma}^{\infty}$ \\
\hline 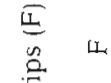 & & & $\stackrel{m}{i} \underset{i}{i}$ & & $\vec{i}$ & \\
\hline G & $\stackrel{0}{-}: 0$ & $=$ & $\stackrel{\circ}{-}:$ & & $\stackrel{\infty}{\infty}$ & $\sum_{\infty}^{\infty}$ \\
\hline 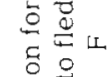 & 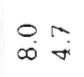 & $\stackrel{\sim}{\sim} \sim$ & \begin{tabular}{ll}
\multirow{2}{*}{} & 0 \\
$i$ & 0
\end{tabular} & & $?$ & \\
\hline 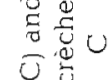 & $\stackrel{-}{\rightarrow}:$ & $\stackrel{9}{-0}$ & $\stackrel{1}{1}: 0$ & & $\stackrel{n}{0}{ }_{0}^{0}$ & $\sum_{\Sigma}^{\infty}$ \\
\hline 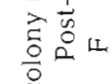 & $\underset{\vec{g}}{+}$ & $\stackrel{\infty}{\stackrel{\sigma}{\sigma}-}$ & $\ddot{g} \dot{s}$ & & $\stackrel{\infty}{\sim} \stackrel{m}{m}$ & \\
\hline$\stackrel{D}{\Xi}_{\vec{\sigma}} u$ & $\stackrel{6}{6}:$ & $\stackrel{9}{-}$ & 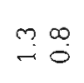 & $\stackrel{0}{-0}$ & :0 & $\sum_{0}^{\infty}$ \\
\hline 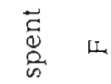 & 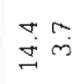 & $\Rightarrow$ & $\stackrel{n}{=}$ & 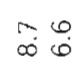 & $\dot{\theta} \overrightarrow{i s}$ & \\
\hline$\underset{0}{\tilde{2}} U$ & mis & $\stackrel{\infty}{\rightarrow} \stackrel{\circ}{\sigma}$ & $\stackrel{+\infty}{i}$ & $\stackrel{0}{i} \stackrel{\infty}{0}$ & $\stackrel{\oplus \rightarrow}{\sim}$ & $\sum_{n=1}^{n}$ \\
\hline 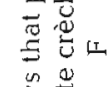 & $\stackrel{\sigma}{=} \widetilde{i}$ & $\stackrel{\leftrightarrow}{\vec{g}} \stackrel{\infty}{\sim}$ & \begin{tabular}{l}
$\infty$ \\
$\stackrel{\infty}{i}$ \\
\cline { 1 - 1 }
\end{tabular} & 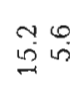 & $\underset{\mathrm{j}}{\mathrm{j}}$ & \\
\hline$\stackrel{\pi}{g} \cdot \frac{\pi}{-1} U$ & $\stackrel{3}{-}$ & $\stackrel{\circ}{i}:$ & $\vec{i} \underset{-}{\square}$ & $\stackrel{\sigma}{\longrightarrow}$ & ב & $\sum_{j}^{\pi}$ \\
\hline 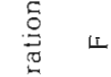 & 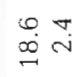 & $\begin{array}{l}0 \% \\
=0\end{array}$ & 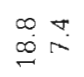 & $\begin{array}{l}\sim \sigma \\
\stackrel{\sigma}{\sigma}\end{array}$ & 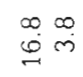 & \\
\hline 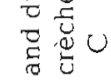 & $\stackrel{\sim}{\sim} \stackrel{\infty}{-}$ & $\stackrel{\sigma r}{i}$ & $\stackrel{m}{c} \stackrel{m}{=}$ & $\stackrel{\sigma}{\sim} \tilde{0}$ & $\stackrel{\circ}{\sim} \stackrel{9}{-}$ & 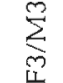 \\
\hline 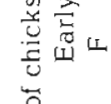 & $\begin{array}{l}n m \\
n \rightarrow\end{array}$ & 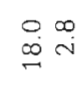 & 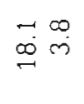 & & $\stackrel{?}{\stackrel{?}{0}}$ & \\
\hline$\stackrel{0}{\mathbb{T}}$ & & $\sqrt{i} \stackrel{\pi}{a}$ & & & & $\tilde{\Sigma}$ \\
\hline$\underset{\Xi}{\stackrel{\Xi}{E}} U$ & $\begin{array}{c}\circ \\
\stackrel{\circ}{\circ}\end{array}$ & 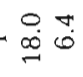 & & & & $\mathbb{L}$ \\
\hline 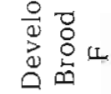 & & & & & & $\bar{\Sigma}$ \\
\hline$u$ & 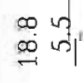 & $=\dot{\infty}$ & & & & $\vec{\Psi}$ \\
\hline & 的拿 & $\times \stackrel{\partial}{\vec{D}}$ & x命 & $\times \stackrel{0}{0}$ & $x \stackrel{\ominus}{0}$ & $\frac{\bar{Q}}{\sigma}$ \\
\hline$\div . \bar{\Xi}$ & $\pi$ & $\underset{\sim}{ }$ & $\stackrel{i}{\sim}$ & $m$ & $\infty$ & $\sum_{\Sigma}^{\prime \prime}$ \\
\hline $\begin{array}{c}\times \\
0 \\
\tilde{u}\end{array}$ & 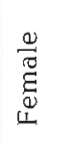 & $\frac{\frac{\partial}{\sigma}}{\sum}$ & 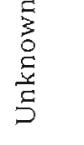 & 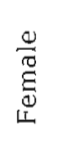 & $\frac{\frac{9}{\pi}}{\frac{\pi}{2}}$ & 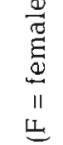 \\
\hline 㐔 & 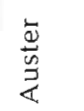 & & & 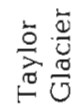 & & 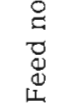 \\
\hline
\end{tabular}


a. Foraging trip durations

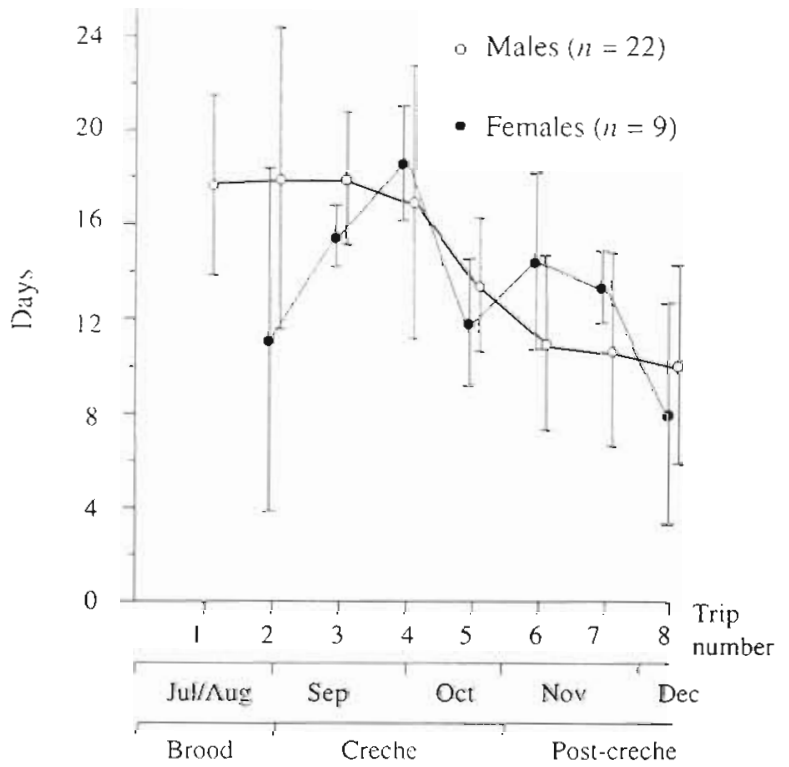

b. Colony attendance durations

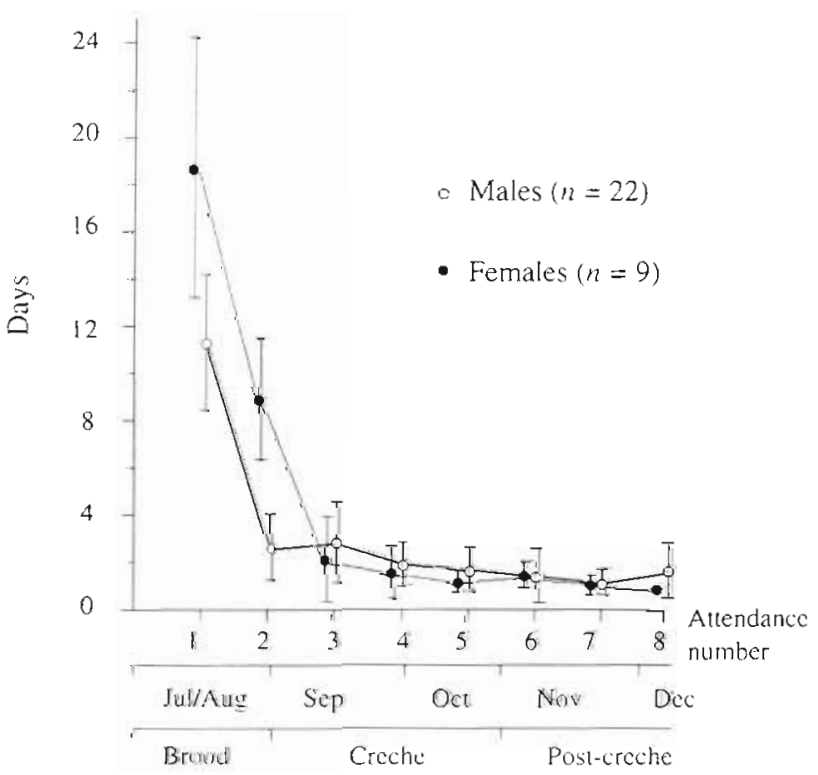

Fig. 7 Aptenodytes forsteri. (a) Foraging trip and (b) colony attendance durations of female and male emperor penguins that raised chicks at Auster colony during 1993 (see Table 5)

recorded for the males $(11.4 \pm 2.9 \mathrm{~d})$. When relieved of the chick by the females for the second time, the males departed for $18.0 \pm 6.4 \mathrm{~d}_{\text {; }}$ however, the females brooded the chicks for just $9.0 \pm 2.6 \mathrm{~d}$ before leaving the chick unguarded at the colony. Therefore parents brooded their chicks for about $40 \mathrm{~d}(38 \pm 3 \mathrm{~d}, \mathrm{n}=7$ penguins) in addition to the time the male brooded the newly hatched chick while awaiting the arrival of the female from her long winter trip. During brooding the chicks received 3 food deliveries, 2 from the female and 1 from the male.

After leaving the chicks unguarded, foraging trip durations by the parents were similar between the sexes and between parents at the 2 colonies (Table 5 , Fig. 7). The trip durations gradually decreased from $15-19 \mathrm{~d}$ in September to $11-15,9-14,8-13$ and $4-10 \mathrm{~d}$ in October, early November, late November and early December, respectively. Periods of attendance at the colony also shortened from about $3 \mathrm{~d}$ in September to between 0.5 and $2 \mathrm{~d}$ in October, November and December.

Combining the data on foraging trip frequencies and durations with prey consumption rates provides an estimate of the amount of prey consumed by the parents during chick raising (Table 6). Between late July and early December, each pair that raised a chick to pre-fledging age consumed approximately $880 \mathrm{~kg}$ of prey, about $470 \mathrm{~kg}$ by the male and about 410 by the female.

\section{DISCUSSION}

\section{Foraging location}

During late winter and spring in 1993, fast-ice covered much of the continental shelf waters along the Mawson Coast. This ice forced the emperor penguins from Auster and Taylor Glacier to forage either in polynyas over the continental slope (the slope polynya), or in pack-ice regions further offshore. Auster penguins may also have foraged in shelf waters $>80 \mathrm{~km}$ to the east of the colony. We assume the slope polynya was the birds' primary foraging area for a number of reasons. Firstly, the single tracked penguin foraged in the polynya during August. Secondly, Antarctic krill and glacier squid Psychroteuthis glacialis which are at their greatest abundances in the vicinity of the slope (Miller \& Hampton 1989, Lu \& Williams 1994) dominated the penguins' diets. Thirdly, the polynya was the closest open water to the colonies and we suspect the breeding penguins would forage as close to their colony as possible to facilitate their regular return to feed chicks. Two satellite tracked emperor penguins from Auster in the 1993 winter also foraged over the continental slope (Kirkwood \& Robertson 1997 a). Slope regions are highly productive areas as a result of nutrient upwelling (Hempel 1985) and it is not unexpected that emperor penguins should forage there during chick rearing.

In early summer 1993, the break-out of fast-ice east of Auster exposed open water within $50 \mathrm{~km}$ of the colony. The ice break-out coincided with a change in 
Table 6. Aptenodytes forsteri. Estimated average prey consumption by emperor penguin couples that successfully raised chicks. Consumption rates are per day away from the colony rather than per foraging day

\begin{tabular}{|c|c|c|c|c|c|c|c|}
\hline \multirow[t]{2}{*}{$\begin{array}{l}\text { Trup } \\
\text { no. }\end{array}$} & \multirow[t]{2}{*}{$\begin{array}{l}\text { Approx. } \\
\text { period }\end{array}$} & \multirow{2}{*}{$\begin{array}{c}\text { Consumption } \\
\text { per day away } \\
(\mathrm{kg})\end{array}$} & \multicolumn{2}{|c|}{$\begin{array}{l}\text { Days } \\
\text { per trip }\end{array}$} & \multicolumn{3}{|c|}{$\begin{array}{l}\text { Prey consumed } \\
\text { per trip }\end{array}$} \\
\hline & & & Male & Fem. & Male & Fem. & Total \\
\hline 1 & Jul and Aug & 2.6 & 18 & $-{ }^{\mathrm{d}}$ & 47 & 47 & \\
\hline 2 & Aug & 2.6 & 18 & 11 & 47 & 29 & 76 \\
\hline 3 & Sep & 3.4 & 18 & 16 & 61 & 54 & 115 \\
\hline 4 & Sep and Oct & 3.4 & 17 & 19 & 58 & 65 & 123 \\
\hline 5 & Oct & 4.0 & 14 & 12 & 56 & 48 & 104 \\
\hline 6 & Oct and Nov & 4.0 & 11 & 14 & 44 & 56 & 100 \\
\hline 7 & Nov & 5.7 & 11 & 13 & 63 & 74 & 137 \\
\hline 8 & Nov and De & 6.8 & 10 & 8 & 68 & 54 & 122 \\
\hline 9 & Dec & 6.8 & 4 & 4 & 27 & 27 & 54 \\
\hline \multicolumn{5}{|c|}{ Total } & 470 & 410 & 880 \\
\hline \multicolumn{8}{|c|}{$\begin{array}{l}\text { "The females' first foraging trip was during winter while males } \\
\text { incubated the eggs }\end{array}$} \\
\hline
\end{tabular}

forming looser schools or being progressively depleted within the penguins' foraging grounds. In contrast with the gradual change from krill to squid, the diet change from squid to shelf-dwelling fish in early summer was abrupt and probably caused by the sea-ice break-out in late November.

In 1988 on the Mawson Coast, there was no obvious seasonal progression in the emperor penguins' diet between winter and early summer (Robertson et al. 1994). Squid and shelf-dwelling fish species dominated the diets on all sampling occasions in 1988, with krill representing only a minor component of the diets (Robertson et al. 1994). Comparing sea-ice images between years, in 1988 (Robertson 1994) the continental shelf was more ice-free than it was in 1993. The penguins probably ate shelf-dwelling fish in 1988 because they were available close to the colony, although a scarcity of krill in the

the penguins' diet from primarily Psychroteuthis glacialis to a range of outer shelf bentho-pelagic or under-ice fish (Trematomus species and Pagothenia borchgrevinki), and a 4 d reduction of the Auster penguins trip durations (from 8-13 to 4-10 d). Before and after the break-out, the penguins' direction on departing the colony did not change. The ice break-out provided the penguins with an opportunity to forage closer to the colony at a time when large, pre-fledging chicks were requiring more frequent food deliveries. We suspect many penguins took this opportunity and foraged over the outer continental shelf during early summer.

\section{Seasonal trends in diet}

The diet of emperor penguins on the Mawson Coast in 1993 went through 3 distinct phases. First was a krill phase that lasted from late winter to mid-spring; the penguins also mainly ate krill in early and mid-winter 1993 (Kirkwood \& Robertson 1997a). Second was the squid phase in late spring when the main prey was a single cohort of immature and rapidly growing Psychroteuthis glacialis. Thirdly, there was a fish phase in early summer when Auster penguins mainly ate shelfdwelling fish species after the sea-ice break-out east of the colony in early summer, as mentioned above. Between the krill and squid phases, the diets changed gradually. Perhaps the immature $P$. glacialis, which live at shallow depths (Piatkowski et al. 1990, Lu \& Williams 1994), became more available or attractive prey as their body size increased. Alternatively, krill may have become increasingly harder to catch, either slope region may also have induced the birds to forage over the shelf in that year Krill can exhibit huge interannual fluctuations in abundance, affecting the foraging behaviours of many Antarctic predators (Croxall et al. 1988). The lack of a seasonal progression in diet during 1988 contrasts with the distinct seasonal trend in diet during 1993, but signals a substantial interannual variation in the diet of emperor penguins from the one location.

Few studies elsewhere have investigated the seasonality of emperor penguin diet. At Amanda Bay $\left(69^{\circ} 17^{\prime}\right.$ $\mathrm{S}, 76^{\circ} 46^{\prime} \mathrm{E}$ ) during chick raising in 1986 , the penguins diet was sampled 3 times between September and November and always comprised $>80 \%$ Pleuragramma antarcticum, indicating there was little change in the diet during the study (Gales et al. 1990). At other locations, single season studies have discovered a variety of prey compositions. Off Adélie Land $\left(66.5^{\circ} \mathrm{S}, 140^{\circ} \mathrm{E}\right)$ during spring, $95 \%$ of the penguins' diet was small nototheniids (possibly $P$. antarcticum or Trematomus species; Offredo \& Ridoux 1986). A.t Dreschler Inlet in the Weddell Sea $\left(72^{\circ} 52^{\prime} \mathrm{S}, 19^{\circ} 25^{\prime} \mathrm{W}\right.$ ) krill constituted $52 \%$ of the emperor penguins' diet in spring 1986 (Klages 1989) and 25\% of the diets in late summer in both 1990 and 1991 (Pütz 1995). Fish species like $P$. antarcticum and Pagothenia borchgrevinki comprised $75 \%$ of the diets at Dreschler Inlet in the 1990 and 1991 summers. The variability of diet between locations emphasises the diversity of the emperor penguins' foraging ability and also the complexity of their trophic relationships. Regular prey of the emperor penguins appear to be predominantly pelagic species such as Antarctic krill, $P$. antarcticum and Psychroteuthis glacialis which exhibit patchy dis- 
tributions (Everson 1983, Hubold 1984, Lu \& Williams 1994). Irregular availabilities of these prey between seasons, years and locations is probably reflected in the penguins' fluctuating diet $\mathrm{mix}$, and highlights the importance of prey switching by emperor penguins to satisfy their food and energy requirements.

\section{Links between prey and diving behaviour}

Krill were the main prey of the Auster emperor penguins between August and October (the first half of the chick raising period) and the birds dived most frequently to depths $<100 \mathrm{~m}$, suggesting the krill lived in abundance at these shallow depths. During August, in conjunction with foraging mainly at shallow depths, the penguins often dived to depths below $100 \mathrm{~m}$. During September and October, as the proportion of squid in the diet increased, the penguins dived deep less frequently. A function of deep diving, which is more energetically demanding than shallow diving, may be to catch large-bodied and potentially more nutritious prey that are not available near the surface (Costa 1991, Kirkwood \& Robertson 1997a). Perhaps in September and October the squid were sufficiently large and available enough to supplement the krill to obviate the penguins' need for deep diving.

Although larger bodied than the krill, the squid taken by the penguins were still relatively small ( $25 \mathrm{~g}$ ) compared with what the penguins are capable of catching (up to at least 500 g; Robertson et al. 1994). We found much of the emperor penguins' prey were small bodied (i.e. $<50 \mathrm{~g}$ ), which is in accordance with the findings of several previous studies. For example. at Amanda Bay in 1986, Pleuragramma antarcticum and Psychroteuthis glacialis taken by emperor penguins averaged just 7 and $3.8 \mathrm{~g}$ respectively (Gales et al. 1990). The body sizes of different prey may influence the penguins' dive frequencies. In October in this study, to catch mainly krill weighing $<1 \mathrm{~g}$ and squid weighing $25 \mathrm{~g}$, the Auster penguins performed an average of 161.6 dives $d^{-1}$. In October 1988, when the diets comprised mostly fish and squid weighing 30 to $500 \mathrm{~g}$, the penguins averaged 113.4 dives $\mathrm{d}^{-1}$ (Robertson 1994). Obviously in 1993 the penguins had to dive more frequently than they did in 1988 to obtain their daily nutritional requirements.

\section{Effect of day-length on foraging}

As day-length increased between August and October, the time taken by penguins to commute the same distance between the colony and the ice-edge reduced from approximately 8 to $2-3 \mathrm{~d}$. The reduction was probably due to the penguins travelling for more hours per day. Although night-time travel by emperor penguins is possible (Ancel et al. 1992), we suspect the reduced light at night slowed their rate of travel and often induced them to stop, which was indicated by d tendency for some birds to huddle at night during their outbound journey (authors' unpubl, data). The shorter travel times later in the year allowed the penguins to spend more days foraging which would reduce the time chicks had to wait between feeds

While at sea, the emperors exhibited a diurnal foraging pattern, resting on the sea-ice at night and entering the water during the day. As day-length increased, their time spent foraging each day increased from approximately $8 \mathrm{~h}$ in August to $13.0 \mathrm{~h}$ in October. In winter, when periods of daylight are short, emperor penguins from Auster spent $<5 \mathrm{~h}$ in the water per day (Kirkwood \& Robertson 1997a), whereas in November, when periods of daylight were long, emperor penguins in the Ross Sea foraged during all hours of the day (Kooyman \& Kooyman 1995).

As day-length increases, emperor penguins dive more frequently, although dive frequency was also influenced by prey size and depth distribution as mentioned earlier. In early winter the penguins performed 62 dives $d^{-1}$ (Kirkwood \& Robertson 1997a), in late winter and early spring the rates were 93 to $162{\text { dives } d^{-1}}^{-1}$ (this study) and in late spring a rate of $213{\text { dives } \mathrm{d}^{-1} \text { has }}^{-1}$ been recorded (Kooyman \& Kooyman 1995). The more dives performed per day enabled prey consumption rates and metabolic energy intakes to increase as the year progressed (see below).

Swimming time per day and dives per day, however, are not directly proportional to day-length because as day-length increased the penguins took more frequent and longer rest periods. Obviously the penguins either tire and/or reach satiation, such that rests are required to recuperate or digest meals. The sea-ice in Antarctic waters provides the emperor penguins with a platform on which they can stand away from predators between diving bouts.

\section{Seasonal changes in prey consumption rates}

Male and female emperor penguins ate twice as much prey per foraging day when providing for small chicks in August $(4.0 \mathrm{~kg})$ than they did when foraging for self-maintenance in winter $\left(1.8 \mathrm{~kg} \mathrm{~d}^{-1}\right.$; Kirkwood \& Robertson 1997a). While increasing day-length provides the opportunity for emperor penguins to forage longer in spring and summer than in winter, increasing requirements of the birds probably provide an impetus to foraging for longer periods. In August, the males had just broken a 4 mo fast, had twice as many hours in 
which to feed as did the females foraging for self-maintenance during winter, and needed to return to the colony as soon as possible to brood and feed their chicks.

To provide for pre-fledging chicks in early summer, the adults apparently ate 5 times the winter, self-maintenance requirements of females. Although the demands on the adults peak at this time of year, and long periods of daylight provide ample time to forage, the consumption of $8.7 \mathrm{~kg} \mathrm{~d}^{-1}$ ( $30 \%$ of body mass) in early summer seems high. A potential source for error with the summer estimates was the prediction that it took the penguins $1 \mathrm{~d}$ to cross the fast-ice to the ice-edge. If it had taken the penguins half the predicted time (i.e. $0.5 \mathrm{~d})$ to cross the fast-ice the estimated prey consumption rates per foraging day would be about $7.6 \mathrm{~kg}$ Without additional information on the trip durations however, we see no reason to modify the calculated consumption rates simply because they seem high. Further study on the feeding rates of emperor penguins in summer is necessary to verify the findings presented here

Each penguin couple at Auster that successfully raised a chick consumed approximately $880 \mathrm{~kg}$ of prey during chick raising. During winter while males were incubating eggs, females consumed about $100 \mathrm{~kg}$ of prey (Kirkwood \& Robertson 1997a); therefore, between May and early December in 1993, each breeding pair that raised a chick ate about $980 \mathrm{~kg}$ of prey This estimate is virtually identical to the $965 \mathrm{~kg}$ required to raise a chick predicted by Robertson \& Newgrain (1996), and suggests that approximately $1000 \mathrm{~kg}$ of food is required each breeding season to maintain 2 adults and raise 1 chick.

Apportioning prey types to the penguins' consumption rates, we estimate that during chick rearing in 1993, each pair of Auster penguins that raised a chick ate approximately $430 \mathrm{~kg}$ of Antarctic krill, $210 \mathrm{~kg}$ of Psychroteuthis glacialis, $100 \mathrm{~kg}$ of Trematomus species, $100 \mathrm{~kg}$ of Pleuragramma antarcticum, $40 \mathrm{~kg}$ of Alluroteuthis antarcticus and $100 \mathrm{~kg}$ of other prey (mainly fish). With approximately 11200 chicks raised to fledging age in 1993 (authors' unpubl. data), the successful parents consumed about $11000 \mathrm{Mg}$ of food, a considerable biomass to be taken from the waters adjacent to the colony.

\section{Food delivery to the chicks}

Our field work at Auster colony ended on 7 December, by which time most females that cycled regularly had returned to feed their chicks 8 times and males had returned either 7 or 8 times. We expect the chicks commenced fledging approximately 1 wk later (see
Robertson 1992). As the adults' trip durations were 4 to $10 \mathrm{~d}$ in length in early December, both parents potentially delivered at least 1 more meal to their chicks prior to their fledging. Therefore, between hatching and fledging, the chicks probably received about 18 to 20 food deliveries. The chick attendance times and food delivery frequencies we recorded at both Auster and Taylor Glacier colonies were similar to those recorded at the Pointe Géologie colony $\left(66.5^{\circ} \mathrm{S}\right.$, $140^{\circ} \mathrm{E}$ ) in the 1950 s (Prévost 1961), and may be similar for all emperor penguin colonies.

There is a discrepancy between the food masses delivered by parents and the requirements of the chicks. Emperor chicks require about $84 \mathrm{~kg}$ of prey to achieve fledging condition (Robertson 1994). With 18 to 20 food deliveries, the parents would have to average about $4 \mathrm{~kg}$ of food per delivery, but from stomach flushed adults we obtained mean wet masses of just 1.3 $\pm 0.6 \mathrm{~kg}$. Mass gains by parents on foraging trips during the 4 to 5 mo of chick raising invariably averaged $4 \mathrm{~kg}$ and during chick rearing the parents gained only a few $\mathrm{kg}$ in body mass, supporting the impression that approximately $4 \mathrm{~kg}$ of prey was delivered to the chicks on each visit. Perhaps stomach flushing was incomplete. Alternatively, much of the stomach contents could have been smaller than the diameter of our sieve. The volumes of food we obtained were similar to those recovered in other studies of emperor penguin diet that employed $0.5 \mathrm{~mm}$ or $1.0 \mathrm{~mm}$ sieves (Klages 1989, Gales et al. 1990, Robertson et al. 1994), but distinctly less than that recovered by Offredo \& Ridoux (1986; 2.4 to $3.6 \mathrm{~kg}$ ) who adopted a $0.25 \mathrm{~mm}$ sieve. Perhaps much of the stomach contents is in an almost liquid form which passed through our sieve. Future studies could solve this potential problem by employing smaller mesh sieves and accurately measuring the volumes of water administered and retrieved during flushing. Another potential explanation for the discrepancy is that chicks may have been fed by adults other than their parents, as described by Jouventin et al. (1995). Although observations of feeding by nonparents was rare (Jouventin et al. 1995), its potential role in chick survival and growth warrants further investigation.

In summary, the trophic inter-relationships between emperor penguins raising chicks and their prey change seasonally in response to fluctuating sea-ice conditions, differences in the prey availabilities, changes in day-length toward summer, and increasing demands of the growing chicks. A prey type targeted by the penguins at any given time might be either preferred over another prey type, or be the only prey available. Managers of fisheries in Antarctic waters need to consider that the degree of direct competition between the penguins and a fishery that targets prey 
of the birds will vary temporally and spatially, and will have different consequences for the penquins depending on the dietary choices available to them at the time.

Acknowledgements. We thank the Mawson 1993 winterers for assistance in the field, the Australian Antarctic Division's science support staff for construction of field equipment, Ian Raymond and Zaheer Abass for providing satellite images of the Mawson Coast, Kate Piggot for assistance sorting the stomach content samples. Dick Williams for identification of fish species, Graham Hosie for providing the estimates of euphausiid body masses and Keith Newgrain for energy determinations of the tood. We also thank Melissa Giese, Mark Hindell, Gerald Kooyman and 2 anonymous referees for their constructive comments on drafts of the manuscript.

\section{LITERATURE CITED}

Adams NJ (1990) Feeding biology and energetics of king (Aptenodytes patagonicus) and gentoo (Pygoscelis papua) penguins at sub-Antarctic Marion Island. PhD thesis, University of Capetown

Ancel A, Kooyman GL, Ponganis PJ, Gender JP, Lignon J, Mestre X, Huin N, Thorson PH, Robisson P, Le Maho Y (1992) Foraging behavior of emperor penguins as a resource detector in winter and summer. Nature (Lond) 360:336-339

Clarke MR (1986) A handbook for the identification of cephalopod beaks. Clarendon Press, Oxford

Costa DP (1991) Reproductive and foraging energetics of high latitude penguins, albatrosses and pinnipeds: implications for life history patterns. Am Zool 31:111-130

Croxall JP (1984) Seabirds. In: Laws RM (ed) Antarctic ecology. Academic Press, New York, p 533-618

Croxall JP, McCann TS, Prince PA, Rothery P (1988) Reproductive performance of seabirds and seals at South Georgia and Signy Island, South Orkney Islands, 1976-1987: implications for Southern Ocean monitoring studies. In: Sahrhage D (ed) Antarctic Ocean and resources: variability. Springer-Verlag, Berlin, p 261-285

Croxall JP, Ricketts C. Prince PA (1984) Impact of seabirds on marine resources, especially krill, off South Georgian waters. In: Whittow GC, Rahn $H$ (eds) Seabird energetics. Plenum Press, New York, p 285-317

Dewasmes G, Le Maho X, Cornet A, Groscolas R (1980) Resting metabolic rate and cost of locomotion in long-term fasting Emperor Penguins. J Appl Physiol 49(5):888-896

Duffy DC, Laurenson LB (1983) Pellets of cape cormorants as indicators of diet. Condor 85:305-307

Everson I (1983) Estimation of krill abundance. Ber Polarforsch $4: 156-168$

Gales NJ, Klages NTW, Williams R, Woehler EJ (1990) The diet of the emperor penguin, Aptenodytes forsteri, in Amanda Bay, Princess Elizabeth Land, Antarctica. Antarct Sci 2:23-28

Hempel G (1985) Antarctic marine food webs. In: Siegfried WR, Condy PR, Laws RM (eds) Antarctic nutrient cycles and food webs. Springer-Verlag, Berlin, p 266-270

Hubold G (1984) Spatial distribution of Pleuragramma antarcticum (Pisces: Nototheniidae) near the Filchner-and Larson Ice Shelves (Weddell Sea/Antarctica). Polar Biol 3: $231-236$

Ichii T, Naganobu M, Ogishima T (1996) Competition between the krill fishery and penguins in the South Shetland Islands. Polar Biol 16:63-70
Jobling $M$, Brieby A (1986) The use and abuse of fish otoliths in studies of feeding habits of marine piscivores. Sarsia 71. $265-274$

Jouventin P, Barbraud C, Rubin M (1995) Adoption in the emperor penguin, Aptenodytes forsteri. Anim Behav 50: 1023-1029

Kirkwood R, Robertson G (1997a) The foraging ecology of female emperor penguins in winter. Ecol Monogr 67(2): $155-176$

Kirkwood R, Robertson G (1997b) The energy assimilation efficiency of emperor penguins, Aptenodytes forsteri, fed a diet of Antarctic krill, Euphausia superba. Physiol Zool $70(1): 27-32$

Klages NTW (1989) Food and feeding ecology of emperor penguins in the eastern Weddell Sea. Polar Biol 9:385-390

Kooyman GL, Drabek RW, Elsner R, Campbell WB (1971) Diving behavior of the emperor penguin, Aptenodytes forsteri. Auk 88:775-795

Kooyman GL, Kooyman TG (1995) Diving behavior of emperor penguins nurturing chicks at Coulman Island, Antarctica. Condor 97:536-549

Lu CC. Williams R (1994) Contribution to the biology of squid in the Prydz Bay region, Antarctica. Antarct Sci 6(2): 223-229

Miller DGM, Hampton I (1989) Biology and ecology of the Antarctic krill (Euphausia superba Dana): a review. BIOMASS Scientific Series, no. 9,1-166

Nagy KA, Costa DP (1980) Water flux in animals: analysis of potential errors in the tritiated water method. Am J Physiol 238:R454-R465

Nicol S, de la Mare WK (1993) Ecosystem management and the Antarctic krill. Am Sci 81:36-47

Offredo C, Ridoux $V$ (1986) The diet of emperor penguins Aptenodytes forsteri in Adélie Land, Antarctica. Ibis 128: 409-413

Piatkowski U, White M, Dimmler W (1990) Micronekton of the Weddell Sea: distribution and abundance. In: Arntz W, Ernst W, Hempel I (eds) The expedition ANTARKTISVII/4 (EPOS leg 3) and VII/5 of RV 'Polarstern' in 1989. Ber Polarforsch 68:73-81

Prévost J (1954) Observations écologiques sur le manchot empereur (Aptenodytes forsteri). Acta XI Congr Intl Ornithol, Basel, p 248-251

Prévost J (1961) Ecologie du manchot empereur. Actualites scientifiques et industrielles. Hermann, Paris

Pütz K (1995) The post-moult diet of emperor penguins (Aptenodytes forstern) in the eastern Weddell Sea, Antarctica. Polar Biol 15:457-463

Robertson G (1992) Population size and breeding success of emperor penguins (Aptenodytes forsteri) at the Auster and Taylor Glacier colonies, Mawson Coast. Antarctica. Emu 92:62-71

Robertson G (1994) The foraging ecology of emperor penguins (Aptenodytes forsteri) at two Mawson Coast colonies, Antarctica. PhD thesis, University of Tasmania, Hobart

Robertson G. Newgrain K (1992) Efficacy of the tritiated water and ${ }^{22} \mathrm{Na}$ turnover methods for estimating food and energy consumption by emperor penguins Aptenodytes forsteri Physiol Zool 65:933-951.

Robertson G, Newgrain K (1996) The food and energy intake rates of adult emperor penguins (Aptenodytes forsteri) rearing chicks. Antarct Sci 8(1):37-44

Robertson G, Williams R, Green K, Robertson L (1994) Diet composition of emperor penguin chicks Aptenodytes forsteri at two Mawson Coast colonies, Antarctica, Ibis 136:19-31

Rodhouse PG, Prince PA, Clarke MR, Murray AWA (1990) 
Cephalopod prey of the grey-headed albatross Diomedia chrysostoma. Mar Biol 104:353-362

Schmidt-Nielsen K (1975) Animal physiology: adaptations and environment. Cambridge University Press, Cambridge

Van Heezik YM, Seddon P (1989) Stomach sampling in the yellow-eyed penguin: erosion of otoliths and squid beaks. J Field Ornithol 60:451-458

Vaughan BE, Boling EA (1961) Rapid assay procedures for HTO-labelled water in body fluids. J Lab Clin Med 57 : $159-164$

This article was submitted to the editor
Williams R, McEldowney A (1990) A guide to the fish otoliths from waters off the Australian Antarctic Territory, Heard and Macquarie Islands. ANARE Research Notes 75, Australian Antarctic Division, Hobart

Wilson RP (1984) An improved stomach pump for penguins and other seabirds. J Field Ornithol 55:109-112

Zwally HJ, Comiso JC, Parkinson CL, Campbell WJ, Carsey FD, Gloersen P (1983) Antarctic sea ice, 1973-1976: satellite passive-microwave observations. NASA, Washington, DC (NASA SP, 459)

Manuscript received: August 9, 1996

Revised version accepted: June 18, 1997 